The Role of Metabolite-sensing G Protein-Coupled Receptors in inflammation and metabolic disease

Carlota Recio $^{1}$, Asif J. Iqbal ${ }^{1}$, Sophia Valaris ${ }^{1}$, Daniel Lucy ${ }^{2}$, Graham Wynne ${ }^{2}$, Angela

J. Russell ${ }^{2}$, Robin P. Choudhury ${ }^{3}$, Chris O'Callaghan ${ }^{4}$, Claudia Monaco ${ }^{5}$, David R. Greaves $^{1}$

Address: $\quad{ }^{1}$ Sir William Dunn School of Pathology, ${ }^{2}$ Department of Chemistry, ${ }^{3}$ Radcliffe Department of Medicine, ${ }^{4}$ Nuffield Department of Medicine, ${ }^{5}$ Kennedy Institute for Rheumatology University of Oxford, Oxford OX1 3RE

Corresponding Author: $\quad$ David R. Greaves david.greaves@path.ox.ac.uk 


\begin{abstract}
Great attention has been placed on the link between metabolism and immune function. giving rise to the term "immunometabolism". It is widely accepted that inflammation and oxidative stress are key processes that underlie metabolic complications during obesity, diabetes and atherosclerosis. Therefore, identifying the mechanisms and mediators that are involved in the regulation of both inflammation and metabolic homeostasis is of high scientific and therapeutic interest. $G$ protein-coupled receptors (GPCRs) that signal in response to metabolites have emerged as attractive therapeutic targets in inflammatory disease. In this review, we discuss recent findings about the physiological role of the main metabolitesensing GPCRs, their implication in immunometabolic disorders, their principal endogenous and synthetic ligands and their potential as drug targets in inflammation and metabolic disease.
\end{abstract}

Keywords: immunometabolism, diabetes, inflammation, oxidative stress, G protein-coupled receptors. 
The traditional view that the role of the immune system is limited to combating pathogens has been challenged over the past decade. It is now recognised that the immune system plays many different roles in regulating endocrine, neural and behavioural responses. Increasing evidence supporting a link between metabolism and immune function has led to the emergence of the term 'immunometabolism'. This concept first appears in PubMed in a foreword to the February 2011 issue of Nature Reviews Immunology by Diane Mathis and Steven Shoelson (99). The authors coined the term to highlight regulatory interactions between innate and adaptive immunity and metabolism. Until around 5 years ago few immunologists appreciated the role metabolism could play in effector cell function and few scientists working in the area of metabolism or systems physiology had fully appreciated the way immune cells impact on metabolic flux and the function of metabolic tissues including white adipose tissue (WAT) and the liver. The term immunometabolism has been given further prominence as we rediscover the important role of metabolic reprogramming in inflammation (69) and cancer biology (126). The value of immunometabolism as a field of scientific study in its own right will be judged ultimately by its success in delivering new insights into the biology of cells of the innate and adaptive immune system, new insights into disease mechanisms and the identification of new targets for therapeutic intervention in metabolic disease.

In this brief review, we will confine our discussion to one specific aspect of immunometabolism, namely the link between innate immune response and metabolic disorders focusing on the G protein-coupled receptors (GPCRs) that have cell or microbial metabolites as agonists. Such receptors are of especial interest to physiologists, pharmacologists and pathologists for two reasons. First, GPCRs that sense changes in cellular metabolites within the physiological range of concentrations are well placed to transduce the effects of changes in cell metabolism on immune cell function. Secondly, new insights into GPCR biology such as biased agonism (170) and structural studies of GPCRs (41) offer new avenues for more effective drug discovery and drug design (both agonists and antagonists). Here we highlight mammalian GPCRs that have been shown to signal in response to cell metabolites and we critically review the role these metabolite-sensing GPCRs play in immunity, oxidative stress and disease pathology. 


\section{Metabolic diseases}

It is known that metabolic diseases have become a worldwide epidemic of the 21 st century. This is especially true of obesity and diabetes mellitus, for both of which global incidence has reached dramatic proportions. This alarming rise in metabolic disorders has been attributed to changes in lifestyle; a predominance of sedentary habits and an excessive consumption of food rich in fats and refined carbohydrates $(117,125)$. The World Health Organization estimates that 600 million people worldwide are clinically obese (122). Obesity is defined as an excessive expansion of adipose tissue and has been recognized as a driving force in the development and progression of comorbidities, such as type 2 diabetes (T2D), insulin resistance, hypertension, dyslipidaemia, atherosclerosis, and fatty liver disease, among others $(44,51,116)$. Collectively, these non-communicable pathologies constitute a major threat to global human health.

Obesity is a great contributor to inflammation and oxidative stress (129). The excess high-fat and carbohydrate diets trigger an increase in oxidative stress as a consequence of a higher number of lipid peroxidation products and a decreased antioxidant activity. Abundant evidence indicates that this oxidative stress and the associated inflammation contribute to the onset and progression of metabolic pathologies including T2D and insulin resistance $(24,112,128,172)$. Tissue inflammation, the synthesis of reactive oxygen species (ROS) and intracellular signalling pathways are strictly regulated to maintain homeostasis and survival. However, in the pathological environment of obesity, an imbalance in redox regulation, impaired inflammatory signalling and dysfunction in insulin secretion and signalling occur with potentially severe consequences (112). It is hoped that a better understanding of the mechanisms that underlie the progression of metabolic disorders may allow us to develop new therapeutic strategies to decrease the prevalence of obesity, diabetes and therefore cardiovascular disease worldwide.

\section{Oxidative stress in metabolic diseases}

Elevated oxidative stress is a key mechanistic link between obesity and its associated metabolic complications (180). Oxidative stress emerges as an imbalance between ROS generation and the activity of the antioxidative systems of cells and tissues. ROS are lowmolecular-weight chemically unstable compounds that derive from molecular oxygen and include superoxide anion $\left(\mathrm{O}_{2}^{-}\right)$, hydroxyl radical $(\bullet \mathrm{OH})$, hydrogen peroxide $\left(\mathrm{H}_{2} \mathrm{O}_{2}\right)$, and peroxynitrite $\left(\mathrm{ONOO}^{-}\right)(65,66,187)$. Although ROS signalling is essential in cell protection 
and survival, an overproduction of oxidative free radicals can result in the modification of the structure and function of biological macromolecules, including DNA damage, lipid peroxidation and membrane protein damage, leading to cellular dysfunction (65). The results of ROS overproduction can include impaired energy metabolism, aberrant cell signalling, cell cycle control and transport mechanism, immune activation and inflammation $(58,66)$.

The major cellular sites of ROS generation are the mitochondrial electron transport chain, membrane-bound nicotinamide adenine dinucleotide phosphate $(\mathrm{NAD}(\mathrm{P}) \mathrm{H})$ oxidase (NOX) isoforms (1-5), dual oxidases (Duox 1 and 2), endoplasmic reticulum, and peroxisomes (112). As one the major sources of ROS in the cell, the mitochondria express the electron transport chain complexes which transfer electrons from NADH and succinate, along a controlled pathway, to the oxygen molecule $\left(\mathrm{O}_{2}\right)$, which is then reduced to $\mathrm{H}_{2} \mathrm{O}_{2}$. When this mechanism is altered, the $\mathrm{O}_{2}$ undergoes one- or two-electron reduction to form $\mathrm{O}_{2}{ }^{-}$or $\mathrm{H}_{2} \mathrm{O}_{2}$, respectively (75).

Phagocytic cells importantly contribute to generate oxidative stress since they produce large amounts of ROS via NADPH oxidase to kill bacteria during the called respiratory burst (127). Furthermore, T cells are often present in close proximity to phagocytic cells and they can also trigger respiratory burst by direct contact with phagocytes or secreted cytokines (184).

ROS levels are regulated by antioxidant enzymes and ROS degradation to keep a non-toxic balance. Antioxidant defences include superoxide dismutase (SOD), catalase or glutathione peroxidase (GSHPx) $(65,112)$.

Oxidative stress is increased in obese individuals, and reduced after weight loss $(67,68)$. Patients with diabetes mellitus have high levels of ROS as well as serum peroxidized fat and oxidized low-density lipoproteins (LDL). In addition, increased ROS levels have also been observed in animal models of diabetes $(25,65)$. High glucose concentrations promote an increase in the production of ROS in several cell types, including pancreatic $\beta$-cells. When intracellular glucose concentrations exceed the glycolytic capacity of such cells, excess glucose is shunted to enolization pathways, resulting in production of superoxide. Moreover, pancreatic $\beta$-cells decrease their expression of antioxidant enzymes, becoming extremely sensitive to oxidative stress (7). In addition to high glucose levels, fatty acids also constitute an important factor in ROS production in pancreatic cells. They control mitochondrial complexes and electron transport, activate $\mathrm{NAD}(\mathrm{P}) \mathrm{H}$ oxidase, induce uncoupling proteins, 
interact with the renin-angiotensin system or modulate the antioxidant enzymes. The amphiphilic nature of fatty acids facilitates their incorporation into mitochondrial membranes which alters the membrane fluidity and favours electron leak (40).

\section{Inflammation in metabolic diseases}

Chronic inflammation plays a key role in the progression of diabetes via abnormal cytokine production, increased recruitment, impaired proliferation, differentiation and altered migration of leukocytes; therefore, a network of inflammatory signalling pathways is globally activated $(6,29,172)$. The first clear evidence that linked obesity, diabetes and chronic inflammation was the finding that the pro-inflammatory cytokine tumour necrosis factor- $\alpha$ (TNF- $\alpha$ ) was overexpressed in the adipose tissue of obese mice (52). Subsequently, numerous studies revealed that the chronic low-grade systemic inflammation associated with obesity is enhanced when immune-inflammatory cells such as macrophages and $\mathrm{T}$ cells infiltrate adipose tissue $(22,60)$. M1, pro-inflammatory, macrophages have been shown to secrete high amounts of inflammatory mediators within the adipose tissue including chemokines (CCL2, CXCL5) and cytokines (TNF- $\alpha$, interleukin (IL)-6, IL-18), which are then released to the bloodstream thereby contributing to systemic inflammation status (123). In peripheral tissues including liver, skeletal muscle and in adipose tissue itself, inflammatory mediators and inflammation-dependent ROS interact with the insulin receptor (IR) and its associated downstream pathways, leading to a dysregulation in insulin response mechanisms (167).

In all these processes that cause tissue damage and metabolic dysregulation, metabolite sensing GPCRs emerge as key mediators that can either promote or oppose inflammation, oxidative stress and impaired metabolism progression- see Figure 1.

\section{Metabolite-sensing GPCRs}

Many key mediators of inflammation and its resolution signal via GPCRs. These receptors constitute the largest family of membrane proteins in mammals and they participate in the regulation of major physiological functions in the organism. GPCRs have the ability to bind to a wide variety of ligands with high affinity and specificity $(2,14,35)$.

The explosion in messenger RNA (mRNA) and genome sequencing in the late 20th century led to the identification of multiple open reading frames containing seven membrane 
spanning $\alpha$-helices reminiscent of GPCRs of known function (174). These so called 'orphan receptors' posed a significant challenge to biologists and pharmacologists because without knowledge of their cognate ligands a full understanding of their role in physiology and pathology was impossible. Within the wide family of GPCRs, a growing number have now been identified as metabolite-sensing GPCRs; this group of deorphanized receptors has been reported to be activated by intermediates of energy metabolism including free fatty acids (FFAs), lactate, succinate and ketone bodies, among others. Owing to their presence in key cell types regulating both metabolic and immune systems, many of them have been shown to have a pivotal role in the progression of metabolic disorders such as diabetes, obesity and dyslipidaemia and in the associated inflammatory response $(3,14,179)$. Therefore, there is intense research interest in this subfamily of metabolic receptors that are emerging as promising therapeutic targets in several immunometabolic disorders, for an excellent recent review see Husted A.S et al. (54).

FFAs have been revealed to be not only important nutrients from dietary fat, but also key signalling molecules that mediate critical biological functions (103). According to the carbon chain length of the FFAs that activate them, the most accepted classification of the metabolite GPCRs divides them into different groups: those activated by long chain fatty acids (LCFA, C12-C22) including GPR120 (FFAR4) and GPR40 (FFAR1); medium chain fatty acid MCFA receptors (C7-C12) highlighting GPR84; and short chain fatty acid (SCFA) receptors (C2-C6) including GPR41 (FFAR3) and GPR43 (FFAR2) (3,164). Blad et al. presented an extended version of metabolite GPCRs classification by adding two other groups to the original list; the group of citric acid cycle intermediate receptors where succinate receptor (GPR91) is highlighted, and secondly the receptors activated by hydroxycarboxylic acids, such as GPR109 (13)- see Table 1.

Once activated by a ligand, metabolite GPCRs can couple to different families of heterometric G proteins (Gs, Gi/Go, Gq/G11 and G12/G13)- see Figure 2- and/or $\beta$-arrestins, then regulating the activity of second-messenger producing enzymes (phospholipases, adenylyl cyclases) or ion channels, which in turn modulate the intracellular concentrations of second messengers (inositol triphosphate (IP3), diacylglycerol (DAG), cyclic AMP (cAMP), calcium, among others) and therefore the downstream signalling within the cell, including different kinase cascades such as ERK/MAPK, JNK, p38, or the Akt/PI3K route. These pathways control cell proliferation, differentiation, survival, migration and other essential biological functions $(2,39,165)$. 
In this review, we summarize the main functions, signalling and expression patterns of the principal metabolic-sensing GPCRs in physiology and disease, highlighting the key role they play in inflammation during metabolic complications.

\section{Long-chain fatty acid receptors}

Major LCFAs present in plasma include palmitic acid (C16:0), stearic acid (C18:0) and several unsaturated fatty acids such as oleic acid (C18:1) or linoleic acid (C18:2). Furthermore, the group of polyunsaturated omega-3 fatty acids ( $\omega 3$-PUFAs), mainly $\alpha$ linolenic acid (ALA, C18:3), eicosapentaenoic acid (EPA, C20:5), and docosahexaenoic acid (DHA, C22:6), although not synthesized by the organism are essential for multiple normal physiological processes. These molecules have been shown to exert anti-inflammatory, antioxidant and anti-diabetic properties, actions which are thought to be GPCR-mediated (104). The potential therapeutic effect of metabolite-sensing GPCRs has been investigated in several diseases including cancer, diabetes, rheumatoid arthritis and inflammatory bowel disease $(30,32,91,160)$. In the last decade, GPR120 and GPR40 have been identified as the most relevant metabolic GPCRs activated by LCFAs (46) -see Figure 3. Recent studies have shown that the administration of selective agonists for GPR120 and GPR40 improve glucose metabolism and ameliorate systemic metabolic disorders $(85,94,140)$.

\subsection{GPR120 (FFAR4)}

GPR120, also called FFAR4, is a rhodopsin-like GPCR subfamily member that was deorphanized in 2005 and it is primarily expressed in adipose tissue, intestine (enteroendocrine L cells in colon), lung and macrophages $(48,87,104)$. Its expression is highly conserved across many species (34). This receptor senses specific LCFAs including $\omega-$ 3 fatty acids and its stimulation results in an elevation of intracellular calcium concentration and an activation of the ERK cascade, thus suggesting interactions with the Gaq family of $G$ proteins (48).

GPR120 activation has been described to display insulin-sensitizing effects, participate in glucose homeostasis and ameliorate chronic low-grade inflammation in vivo (121). Furthermore, its activation by $\omega-3$ FFAs has shown to be involved in glucagon-like peptide-1 (GLP-1) secretion in the intestine. GPR120 acts as a lipid sensor in adipose tissue to sense dietary fat and control energy balance $(87,104)$. In mice, GPR120 expression has been 
detected in pancreatic delta cells regulating somatostatin secretion from islets (152). In addition, its expression has been described in the immune system, mainly in innate immune cells (121).

GPR120-deficient mice have shown to develop obesity, glucose intolerance, and hepatic steatosis. In addition, the lack of GPR120 is associated with impaired glucose metabolism and heightened lipogenesis when compared to control mice both fed a high fat diet (HFD) containing $60 \%$ fat. Likewise, in humans a dysfunctional variant of GPR120 is associated with metabolic complications including obesity (55). The anti-inflammatory effects of GPR120 have been widely observed in the immune system mainly in macrophages, a cell type where the receptor is highly expressed. Macrophage-expressed GPR120 couples to $\beta$ arrestin 2 which is followed by receptor internalization and inhibition of both the toll like receptor-4 (TLR4) and TNF- $\alpha$ pro-inflammatory signalling pathways (121). It is well established that chronic inflammation is a key factor in the pathogenesis of insulin resistance involving the migration of monocytes and macrophages into adipose tissue and liver where they amplify inflammation by activating pro-inflammatory pathways and cytokine secretion, eventually leading, through paracrine effects, to decreased insulin sensitivity in nearby insulin secreting cells $(138,144)$. In line with this, the anti-inflammatory effect of GPR120 in macrophages seems to be linked to insulin sensitivity in diabetic conditions.

Conflicting reports on the role of GPR120 in mediating the actions of $\omega-3$ FFAs are emerging. On one hand, most studies agree that GPR120 per se has an important role in energy homeostasis and inflammation independent of the presence or absence of $\omega-3$ FFAs $(55,104,121,186)$. However, the role GPR120 plays in mediating the beneficial effects of $\omega-3$ FFAs by inducing an anti-inflammatory response and regulating insulin metabolism is discussed by Pærregaard et al. (124). In their latest study, and contradicting most existing literature, they proposed that GPR120 is dispensable for the beneficial effects that $\omega-3$ FFAs display in obese mice. GPR120 knockout mice and their controls were fed a with a high dose of $\omega$-3 FFAs and both groups showed protection against HFD-induced obesity, steatosis, insulin resistance, and visceral adipose tissue inflammation, consistent with no role for GPR120 in the therapeutic effects of $\omega$-3 FFAs.

Questions remain about the role of GPR120 in immunometabolism. The beneficial effect that this receptor in maintaining metabolic homeostasis has been widely accepted, thus GPR120 is emerging as a potential therapeutic target to treat diabetes and inflammation. The question 
that needs to be clarified is which would be the optimal GPR120-based therapy: the use of selective GPR120 agonists, a modified diet rich in $\omega$-3 FFA components, or a combination of both?

\subsection{GPR40 (FFAR1)}

GPR40, also called FFAR1, was first identified in 1997 (137). It is physiologically activated by saturated and unsaturated medium and long-chain FAs (C8:0-C22:0) as well as by conjugated linoleic acids (CLAs). Its expression has been described to be mainly in pancreatic $\beta$-cells, but GPR40 is expressed in the central nervous system, in the taste buds, in innate immune cells and enteroendocrine cells $(16,21,28,57,93)$. In enteroendocrine cells GPR40 has been reported to participate in the production of regulatory peptides GLP-1 and gastric inhibitory polypeptide (GIP), which are key regulators of glucose metabolism (28).

Since its deorphanization, GPR40 has been seen as an interesting therapeutic target for T2D treatment due to its implication in mediating fatty acid mediated insulin secretion $(36,57)$. However, conflicting data have emerged regarding the role of this G-coupled protein receptor in metabolic homeostasis. Stenberg et al. reported that mice lacking GPR40 were protected against effects of HFD, including hyperglycemia, hyperinsulinemia and glucose intolerance. In addition, transgenic mice overexpressing GPR40 in $\beta$-cells displayed a diabetic phenotype (150). These results support GPR40 antagonists as a potential therapeutic approach to prevent and treat T2D. A GPR40 antagonist (DC260126) has been reported to protect pancreatic $\beta$ cells against endoplasmic reticulum stress, dysfunction and apoptosis (153,175). Moreover, exendin-4, a GLP-1 mimetic drug, was shown to counteract the proapoptotic effect of palmitate in $\beta$-cells by reducing GPR40 expression (111).

In contrast to these findings, several studies have reported the beneficial effect of GPR40 activation in diabetes, increasing insulin secretion and improving glucose tolerance in murine $\beta$-cells $(77,106)$. Numerous drugs that act as specific GPR40 agonists are either in clinical (TAK-875, JTT-851, P11187 and LY2881835) or in preclinical (CNX-011-67, SAR1, DS1558 and BMS-986118) development $(26,59,82)$. However, most of these tool compounds have been investigated for their beneficial effect in GPR40 mediated-insulin secretion without any attention focused in their relationship with FFA mediated-lipotoxicity. Studies have shown that peroxisome proliferator activated receptor gamma (PPAR $\gamma$ ) agonists, which activate GPR40, induce resistance to lipotoxicity in $\beta$-cells (46). In agreement with this, the anti-lipotoxic effect of the PPAR $\gamma$ agonist pioglitazone in $\beta$-cells has shown to be weakened 
after silencing the expression of GPR40 (176). Shen et al. further revealed that the role of GPR40 mediating the anti-oxidative stress effect of pioglitazone occurs through activation of the phospholipase C (PLC) $\gamma$-ERK1/2-PPAR $\gamma$ signalling pathway (142). Activation of PLC by GPR40 activation leads to the hydrolysis of phosphatidylinositol 4,5-bisphosphate (PIP2) into DAG and IP3. DAG and IP3 potentiate insulin secretion by activating protein kinase C (PKC) and triggering endoplasmic reticulum (ER) Ca2+ release, respectively (76).

Interestingly, a potential role of GPR40 in reducing inflammation has been reported. Activation of GPR40 by an agonist (CNX-011-67) was reported to attenuate inflammatory signalling by improving calcium flux and cAMP levels in $\beta$-cells. This anti-inflammatory role of GPR40 involves a reduction in inflammatory signalling molecules such as nuclear factor kappa-light-chain-enhancer of activated B cells $(\mathrm{NF \kappa B})$ and $\mathrm{JNK}$, in inflammatory cytokine gene expression, and in cellular oxidative and ER stresses (168). It will be interesting to explore the anti-inflammatory effects of this GPR40 agonist in other cell types including immune cells including macrophages and polymorphonuclear (PMN) cells. Recent evidence suggests that GPR40 is expressed in bovine neutrophils, where it displays an important role on PMN activation (96). Through PLC-PKC signalling, GPR40 activation by oleic and linoleic acids triggers the release of metalloproteinase-9 (MMP-9) granules and ROS production in neutrophils. Therefore, depending on the ligand that binds the receptor, the cell type and the tissue-environmental conditions, different roles on inflammation can be attributed to GPR40.

The expression of GPR40 in the brain has been extensively described, where this receptor exerts interesting neuroprotective properties (107-109). Mice lacking GPR40 were shown to develop inflammation and insulin resistance induced by CLAs in the brain, thus providing evidence for a protective role of the receptor in neuronal inflammation (136). This neuroprotection may come from GPR40 dependent stimulation of insulin and GLP-1 secretion $(28,139)$. Activation of GPR40 signalling at the spinal level also appears to be effective in reducing peripheral inflammation and nerve injury-induced pain, suggesting that GPR40 could be a promising therapeutic target for new analgesic drug development (64).

Taken together, the potential role of GPR40 in improving insulin resistance, maintaining glucose homeostasis and preventing inflammation in pancreatic $\beta$-cells makes a compelling case for GPR40 as a drug target in metabolic disease. Current clinical studies indicate that specific GPR40 activation in pancreatic $\beta$-cells achieves the initially therapeutic endpoint for 
the treatment of T2D, and consequently the pharmaceutical industry has shown a clear interest in developing effective GPR40 agonists.

\section{Medium-chain fatty acid receptors}

\subsection{GPR84}

An open reading frame predicted to encode a protein with seven membrane spanning $\alpha$ helices was independently identified by two groups in 2001 and termed GPR84 $(174,181)$. Wang et al. showed that CHO cells transfected with a human GPR84 expression vector along with an aequorin reporter and Ga16, Gqi9 and Gqs5 expression vectors exhibited concentration dependent luminescent signalling with the MCFAs capric -see compound 1 in Figure 4 - and undecanoic acid (C11:0). Similar results were obtained with CHO cells transfected with a murine GPR84 expression vector (85\% amino acid homology with human GPR84). Using stably transfected GPR84-CHO cells the authors demonstrated $\mathrm{EC}_{50}$ values for capric acid in cAMP inhibition assays of $4 \mu \mathrm{M}$, undecanoic acid of $8 \mu \mathrm{M}$ and dodecanoic (lauric) acid (C12:0) of $9 \mu \mathrm{M}$. Importantly the authors found no evidence of GPR84 signalling in transfected cell systems in response to short chain fatty acid ligands of GPR43 or long chain fatty acid agonists of the GPR120 receptor. Wang et al. further demonstrated high-level expression of human GPR84 mRNA in human peripheral blood leukocytes, specifically neutrophils and lipopolysaccharide (LPS) stimulated monocytes. Structural homology searches show only limited amino acid sequence homology of GPR84 with free fatty acid receptors FFAR1-4. Rather, GPR84's closest homologues seem to be monoamine receptors (171). Finally, a potential role for GPR84 in inflammation was suggested by the authors' observation that LPS-stimulated RAW264.7 cells treated with a GPR84 agonist diindolylmethane 2 (DIM) - also active at the cannabinoid receptor CB2 (178) or the MCFAs capric, undecanoic and lauric acid induced IL-12 p40 mRNA and that this effect of GPR84 ligands was not observed without prior LPS treatment. The authors interpreted this to mean that GPR84 agonists acting via the macrophage GPR84 receptor amplified macrophage inflammatory responses. Hence GPR84 is considered a pro-inflammatory GPCR and physiological GPR84 agonists are considered pro-inflammatory.

Suzuki et al. reported that a novel GPR84-specific tool compound 6-n-octylaminouracil 4 (6$\mathrm{OAU}$ ) is more potent than hydroxylated or native MCFAs $\left(\mathrm{EC}_{50}\right.$ values of $\sim 500 \mathrm{nM}$ for 6 - 
OAU versus $\sim 4 \mu \mathrm{M}$ for capric acid) (154). The novel GPR84 surrogate agonist 6-OAU was shown to enhance IL-8 secretion from LPS-stimulated human neutrophils. Further small molecule screening programmes identified more agonists active at the human GPR84 receptor expressed in transfected cell systems. Zhang et al. screened a HEK/G $\alpha 16 / \mathrm{hGPR} 84$ cell line with a 160,000-compound library in agonist and antagonist mode and identified compound 5 -see Figure 4- as a GPR84 specific agonist with a 5-fold increased potency compared to 6-OAU (185). The same group subsequently performed a structure activity study based on the compound 5 and identified the 6 - see Figure 4- as the most potent GPR84 agonist so far described $\mathrm{EC}_{50} 352 \mathrm{pM}$ versus $\mathrm{EC}_{50} 438 \mathrm{nM}$ for 6-OAU in the same transfected cell line calcium flux assay (90).

Consideration of the relative potencies of 'surrogate' and 'physiological' agonists of the GPR84 receptor raises an important question - why is signalling at this GPCR by physiological MCFAs so weak compared to that obtained with tool compounds? One potential explanation is that results obtained from transfected cell line assays are poorly representative of GPR84 signalling in primary cells in vitro or in vivo. An alternative explanation is that physiological agonists other than MCFAs may exist in vivo, perhaps in inflamed adipose tissue or atherosclerotic lesions, or that GPR84 in vivo is part of a GPCR oligomeric signalling complex which responds to MCFCs in vivo differently to the way GPR84 alone does when transfected into cell lines in vitro. Additionally consideration must be given to the possibility that MCFA concentrations could differ considerably between different anatomical sites. For instance enteroendocrine cells in the gut could well be exposed to higher concentrations and a wider range of MCFA metabolites.

In 2005, Venkataraman and Kuo reported the generation of GPR84 knockout mice (166). Mice lacking the GPR84 gene were healthy and fertile and showed no defect in T lymphocyte or B lymphocyte proliferation to a range of mitogens. However, CD3+ T cells of Gpr84-/mice showed increased IL-4 gene transcription and IL-4 production when stimulated with anti-CD3 antibodies. Differentiation of Gpr84-/- T cells in vitro under Th2 conditions resulted in decreased secretion of the Th2 cytokines IL-4, IL-5 and IL-13 but no change in serum levels of these cytokines was seen in vivo after ovalbumin immunization. Subsequent studies identified differences between Gpr84-/- and wild-type mice in a partial sciatic nerve ligation model of neuropathic pain and accelerated cognitive decline and decreased numbers of microglia in a mouse model of Alzheimer's disease (113). No obvious difference was seen in the pathogenesis of experimental autoimmune encephalomyelitis (EAE) or mouse 
behaviour post endotoxin administration in Gpr84-/- compared to wild-type mice (8). In looking for potential mechanistic explanations of the effect of Gpr84 gene deletion on pain perception Nicol et al. performed a differential gene expression analysis of peritoneal macrophages treated with LPS for 3 hours and identified multiple changes in gene expression consistent with attenuated pro-inflammatory signalling in Gpr84-/- macrophages (113). There are currently no published reports linking genetic variation in the human GPR84 gene locus with human disease.

\section{Short-chain fatty acid receptors}

SCFAs mainly acetate $(\mathrm{C} 2: 0)$, propionate $(\mathrm{C} 3: 0)$ and butyrate $(\mathrm{C} 4: 0)$, are produced in the colon by gut microbial fermentation of dietary fibre and they are emerging as important regulators of inflammatory responses (155). Their biological functions in energy metabolism homeostasis and immune response are mainly linked with the activation of the G-coupled metabolic receptors GPR41 and GPR43 (4). Interestingly, the combination of SCFAs and their associated receptors has recently been suggested as the potential link between diet, gut microbiota and inflammatory response (97). Indeed, epidemiological studies have connected the increased incidence of inflammatory disorders and intestinal cancers to the consumption of diets poor in fibre and rich in refined carbohydrates (147).

GPR41 and GPR43 are mainly expressed in colon epithelial cells close to the major site of SCFA production, and also in adipose tissue, pancreatic islets, and immune cells $(4,17,114)$. Their activation has been reported to be involved in different chronic inflammatory and metabolic diseases such as rheumatoid arthritis, inflammatory bowel disease (IBD), asthma, colon cancer, diabetes and obesity, but so far whether their role is beneficial or detrimental is controversial between different studies $(13,37,70,98,100,161,163)$.

Both SCFA receptors respond to the same endogenous ligands, but GPR41 and GPR43 couple to different downstream signalling pathways (72). After activation by SCFAs, GPR41 selectively couples with Gai, inhibiting adenylyl cyclase, thereby decreasing intracellular cAMP concentration. In contrast GPR43 binds both Gai and Gaq, which not only decreases cAMP but also increases cytoplasmic calcium levels $(17,80)$. Furthermore, a recent study revealed that GPR43 can regulate NFKB pathway by coupling with $\beta$-arrestin 2 , but there is no report linking GPR41 to $\beta$-arrestins (81). 


\subsection{GPR41 (FFAR3)}

There is little information about the role of GPR41 in inflammation and metabolism. It is known that GPR41 is broadly expressed in the pancreas, intestine, monocytes, T and B cells, and spleen. Although its expression was first described in human and rodent adipose tissue, current controversy exists about GPR41 expression in this tissue, because several groups have tried to detect it without success $(17,80,177)$. However, others have detected GPR41 expression, reporting that SCFA-induced GPR41 activity stimulates the production of the hormone leptin in mouse white adipose tissue cells $(177,182)$. GPR41 is also expressed in enteroendocrine cells where it has been implicated in SCFA-mediated GLP-1 and PYY hormone secretion, thus participating in metabolic homeostasis $(133,158)$. Few studies have reported a role for GPR41 role in inflammation. In one of them, Kim et al. showed that mice lacking GPR41 presented reduced colitis, whereas in a later study Trompette and co-workers reported exacerbated asthma in GPR41 deficient mice $(70,161)$.

There is current absence of publications reporting a significant effect of GPR41 modulation in disease models, compared to the other SCFA receptor GPR43. Regarding its expression in $\mathrm{T}$ and $\mathrm{B}$ cells, further studies would be interesting to elucidate if this receptor participates in the regulation of the adaptive immune response.

\subsection{GPR43 (FFAR2)}

Deorphanization of this receptor took place simultaneously with GPR41 in 2003. However, the studies about the role of GPR43 in disease are immensely larger. GPR43 is highly expressed on innate immune cells, specially neutrophils $(17,80,114)$. Its activation appears to be regulated during inflammation by LPS or TNF- $\alpha$, which have shown to raise GPR43 levels in human monocytes $(5,141)$. Consistently, luciferase reporter assays have identified inflammation-associated NFKB transcription factor-binding sites within the GPR43 promoter (143).

SCFAs induce chemotaxis of neutrophils via GPR43 in p38, ERK and Akt-dependent manner $(80,98,145,169)$ - see Figure 5. In fact, genetic and pharmacological inhibition of PI3K, p38 and ERK dramatically reduced the GPR43-dependent chemotaxis. In addition, this response is sensitive to pertussis toxin treatment, indicating the involvement of Gai in the process (169). However, recent studies have refuted this concept, reporting that GPR43 acts as an anti-inflammatory chemoattractant receptor in neutrophils in a model of IBD (98). Maslowski 
et al. showed that mice lacking GPR43 presented exacerbated inflammation (more PMN recruitment and chemotaxis, higher ROS production, and increased expression levels of key inflammatory mediators such as CXCL1 or TNF- $\alpha$ ) in dextran sulphate sodium (DSS) induced colitis, indicating that the GPR43-dependent effects of SCFAs are crucial for the normal resolution of intestinal inflammatory responses. Furthermore, greater intravascular neutrophil rolling and adhesion was observed in GPR43 knockout mice in response to LPS (61). Several contradictory results have been reported, about the role of GPR43 in IBD. Sina et al. reported that GPR43 deficient mice exhibited decreased inflammation in a DSS-induced colitis model, and in particular a reduced infiltration of neutrophils was observed (145). Thus, the question whether GPR43 exacerbates or reduces inflammation in the intestine remains unclear.

In the kidney, GPR43 activation by SCFAs or specific agonists has been shown to inhibit glomerular mesangial cell proliferation induced by high glucose and LPS. Receptor activation also reversed the production of ROS and malondialdehyde and increased expression levels of antioxidant enzymes. Likewise, GPR43 agonism also diminished the expression of adhesion molecules and pro-inflammatory cytokines such as MCP-1 and IL-1 $\beta$ from mesangial cells, suggesting a possible role of the receptor in diabetic nephropathy (53).

The action of SCFA/GPR43 signalling on inflammation and oxidative stress generation has been proposed to work through the Th17 response and NOX activation, respectively. Psoriatic mice treated with either acetate or a GPR43 agonist showed an increase in skin inflammation with upregulated Th17 immune responses and epidermal dual oxidase-2 signaling (105). But again, the effects of SCFA receptors on ROS production remain controversial. Some studies have shown a GPR43-mediated induction of ROS $(98,110)$, whereas others have shown ROS inhibition $(88,134,169)$.

GPR43 is expressed in intestine and adipose tissue, where it has been proposed to play a role in secretion of hormones and regulation of appetite (148). Interestingly, metabolic studies in GPR43 knockout mice appear to have consistent findings, consistent with GPR43 having a protective role against obesity and diabetes $(73,100,159)$. GPR43 in enteroendocrine cells is involved in secretion of peptide YY (PYY), a hormone that decreases appetite $(62,63)$. Additionally, it was demonstrated that GPR43 mediates SCFA-induced incretin hormone GLP-1 release in L enteroendocrine cells, thus indirectly participating in regulation of insulin 
secretion and sensitivity (159). In adipose tissue, GPR43 regulates SCFA-mediated adipogenesis and adipocyte differentiation in mice (49).

Taken together, although there is much evidence showing that GPR43 and GPR41 are implicated in pathological metabolic and inflammatory processes, there are contradictory results about the beneficial or detrimental effects of activating these receptors in animal models. Furthermore, which direction of modulation (agonism or antagonism) would provide therapeutic effects is also under debate. The numerous discrepancies may be due to differences in the disease models used and/or non-specific gene knockout effects. Therefore, a further understanding and consensus will be necessary to launch GPR43 and GPR41 as pharmacologically valuable drug targets. Cell type specific knockout mice for GPR43 or GPR41 could be a useful approach to address this question as would specific small molecule modulators at these receptors (151).

\section{Succinate receptor}

\subsection{GPR91 (SUCNR1)}

In 2004 the biotechnology company Tularik published a landmark study that identified physiological ligands for not one, but two, orphan GPCR genes expressed at a high level in the kidney. Their experiments identified succinate as the major physiological agonist of GPR91 and $\alpha$-ketoglutarate as the agonist of GPR99. He et al. demonstrated that the citric acid cycle metabolite succinate is a full agonist at the human, mouse and rat GPR91 receptors expressed in transfected 293 cells and that signaling occurred partly via the pertussis toxin sensitive Gai pathway and via the pertussis toxin insensitive Gq pathway (47). Confirmation that succinate was physiologically active and that GPR91 was its unique receptor came from experiments performed using GPR91 knockout mice where administration of increasing doses of succinate raised mean arterial blood pressure via increased renin secretion in wildtype but not GPR91 knockout mice. Of note in this original description of GPR91 as a metabolite sensing GPCR was the high $\mathrm{EC}_{50}$ of this receptor for succinate (low millimolar) compared to more traditional GPCRs previously shown to mediate hypertension and typical plasma levels of succinate (low micromolar). The authors of this original study suggested that pathophysiological relevance of succinate may lie in situations where blood supply to the kidney is restricted such as renal atherosclerosis or ischaemia. In 2014, Hamal et al. 
demonstrated accumulation of succinate and functional activity of GPR91 in rodent models of cerebral post-hypoxia-ischemia revascularization (43). In the same year, Chouchani et al. identified a significant link between succinate and cardiac reperfusion injury using metabolomic approaches to demonstrate a link between succinate and mitochondrial ROS production but their work showed no role for extracellular succinate signaling via GPR91.

The 'deorphanisation' of GPR91 and the availability of GPR91 knockout mice led to multiple reports linking succinate and GPR91 with the dendritic cell biology (131), haematopoiesis (42), hepatic stellate cell activation in liver damage (23,84), lipolysis in adipose tissue (130) and retinal angiogenesis (135). The intriguing link between Krebs cycle intermediates and cell signaling that started with the pioneering work of $\mathrm{He}$ et al. has played an important role in the emerging concept of immunometabolism (47). O'Neill and co-workers have heralded succinate as a central player in the link between metabolism, ROS and innate immune cell activation in inflammation $(102,115,157)$.

The causal links between GPR91 and hypertension, immunity and inflammation seen in the pre-clinical models outlined above lead to an obvious question - is the GPR91 succinate receptor a suitable drug target in human disease? Early work identified two orally bioavailable small molecule hGPR91 selective antagonists that were capable of blocking hypertensive responses to succinate infusion in rats (12). Taking as their starting point a report showing elevated levels of succinate in synovial fluid of rheumatoid arthritis patients (71), Littlewood-Evans et al. co-incubated activated human myeloid U937 cells with succinate or with supernatants of synovial fibroblasts from rheumatoid arthritis patients and showed that the GPR91 antagonist GPR91A1 reduced succinate induced macrophage IL-1 $\beta$ secretion in vitro (86). The authors then compared wild-type and Gpr91 knockout mice in an antigen induced arthritis model. Knee swelling was reduced 48\% in Gpr91 deficient animals and this effect was shown to be conferred by bone marrow derived haematopoietic cells, most likely synovial monocyte-derived macrophages. This recent report suggests that GPR91 is a potential therapeutic target in rheumatoid arthritis due to the role of succinate in autocrine and paracrine amplification of macrophage inflammation - see Figure 6. Definitive evidence that GPR91 antagonists can act as novel anti-inflammatory drugs in vivo must await intervention studies in murine or rat inflammatory disease models and proof of concept studies in human volunteers. 


\section{Niacin receptors}

Niacin also known as vitamin B3 and nicotinic acid has been used for over 50 years to treat dyslipidemia in patients at increased risk of atherosclerotic disease. Niacin in either an immediate release-or extended-release formulation has been shown to act on multiple cell types to reduce plasma LDL, decrease plasma triglyceride (TG), decrease plasma Lipoprotein (a) and elevate HDL - see Figure 7. These effects are rapid and significant, typically causing a $20-30 \%$ decrease in plasma lipids $(19,20)$.

The GPR109A, GPR109B and GPR81 receptors are a genetically linked and highly related cluster of immunometabolic receptors. They are mainly expressed in adipocytes where they signal in response to metabolites including 3-hydroxybutyrate, lactate and 3-hydroxyoctanoate $(1,120)$.

\subsection{GPR109A / HCA2 / HM74A/ PUMA-G}

In 2003 three groups independently demonstrated that GPR109A was a receptor for niacin and that GPR109A mediated niacin's anti-lipolytic effects in adipose tissue $(149,162,173)$. Importantly, Gpr109a deficient mice showed no decrease in plasma FFA or TG following niacin treatment (162). An almost universal adverse effect of niacin is increased blood flow to the skin and associated skin inflammation and irritation - an effect known as 'flushing'. This significant adverse effect of niacin is mediated by GPR109A receptors expressed on keratinocytes and other non-haematopoietic cells in the skin. Prostaglandin synthesis in response to niacin causes Langerhans cell activation via prostaglandin D2 receptor 1 (DP1) $(10,11,45)$ reviewed in $(27)$. These observations prompted the development of a new formulation of niacin with a D1 receptor antagonist laropiprant to increase patient compliance.

In addition to its anti-atherogenic effects on plasma lipids, niacin has anti-inflammatory effects, which have been ascribed to GPR109A-expressing immune cells (118). Of note, monomethylfumerate (MMF), a metabolite of the anti-psoriasis and MS drug Dimethyl fumarate, was identified as a potent GPR109A agonist with an $\mathrm{EC}_{50}$ of $9.4 \mu \mathrm{M}$ versus niacin $2.0 \mu \mathrm{M}$ in GPR109A transfected CHO cells (156). The tolerability of statins and their efficacy in lowering plasma LDL cholesterol and reducing the risk of cardiovascular events in multiple randomized clinical trials left clinicians with the question what to do with niacin. Early advice was to combine statins with niacin to effect even greater decreases in plasma 
LDL. Fifty years after its first therapeutic use, niacin remains one of very few drugs that can increase anti-atherogenic HDL levels but whether this was of clinical value was unclear. For this reason, the results from two clinical trials AIM-HIGH and HPS2 THRIVE were eagerly awaited. The clear result from 25,673 vascular disease patients enrolled in the HPS study was that adding extended-release form of niacin and laropiprant to standard statin therapy did not significantly reduce cardiovascular disease events but did increase the risk of serious adverse drug effects (78). With the arrival of newer non statin LDL lowering agents such as ezetimibe and anti-proprotein convertase subtilisin/kexin type9 (PSCK9) drugs $(15,33)$ there seems to be no use for niacin as a lipid lowering agent unless we can identify specific patient groups where there is a clear therapeutic benefit in activating the GPR109A receptor.

Consideration of the GPR109A literature, especially as it relates to pre-clinical models, suggests that the anti-inflammatory potential of GPR109A agonists remains under exploited. Early reports demonstrated niacin induction of the scavenger receptor CD36 and ATPbinding cassette transporter (ABCA1) expression in human myeloid cells likely via transcriptional activation of PPAR $\gamma$ and prostaglandin synthesis $(74,132)$. More detailed consideration of disease mechanisms in Gpr109a-/- knockout mice in animal models of atherosclerosis have revealed interesting avenues for further study. Lukasova et al. reported that nicotinic acid (NA) was able to inhibit atherosclerosis in male Ldlr-/- mice but not Ldlr/-, Gpr109a-/- double knockout mice. Importantly the anti-atherogenic effect of NA was not accompanied by any change in plasma cholesterol or HDL levels. The authors used bone marrow transplantation experiments to demonstrate that the anti-atherogenic effect of NA was associated with radiosensitive GPR109A expressing haematopoietic cells. Intriguingly the authors demonstrated that NA treatment inhibited macrophage recruitment to the peritoneum following MCP-1 injection into wild-type but not Gpr109A-/- mice. This finding was corroborated by following the recruitment of fluorescently labeled macrophages into Ldlr-/- mouse atherosclerotic lesions of NA treated mice (92).

It is not immediately obvious how GPR109A signalling interferes with chemokine recruitment of monocytes and macrophages. Understanding exactly how GPR109A agonists interfere with monocyte chemoattraction in vivo and in vitro might could lead to new antiinflammatory strategies (183). In a subsequent paper Lauring et al. studied the effect of niacin on atherosclerosis and lipid lowering in Ldlr-/- mice expressing the human cholesterol ester transfer protein (CETP). Lauring et al concluded that in their animal model of atherosclerosis the GPR109A receptor is not responsible for the beneficial lipid effects of niacin (79). 
A subsequent study by Singh et al. revealed a subtle cellular phenotype in Gpr109A-/- mice, with $40 \%$ fewer IL-10 producing CD4+ T cells and more IL-17A producing CD4+ T cells present in the colon (146). Interestingly Gpr109A-/- colonic epithelium showed a defect in expression of the cytokine IL-18 providing evidence of a potential link between the niacin receptor and inflammasome activation. The importance of these cellular changes was demonstrated by increased colonic inflammation when Gpr109A-/- mice were used in the DSS colitis model and increased polyp formation when mice were dosed with azoxymetane (AOX) and DSS.

For a drug used for over 50 years in the treatment of human cardiovascular disease, niacin and its G protein coupled receptor GPR109A remain enigmatic when it comes to mechanism, not least the mechanistic basis of the anti-atherogenic and anti-inflammatory effects. Nevertheless, the HPS THRIVE randomized clinical trial showed that no additional therapeutic benefit was derived from the addition of niacin to statins in humans and there is little current enthusiasm to identify novel GPR109A agonists as a new class of antiinflammatory drugs.

\subsection{GPR109B / HCA3}

In vitro experiments have shown that GPR109A and GPR109B heterodimerise in transfected HEK cells but so far there is no evidence for altered signaling by heterodimers or signal induced heterodimerisation (95). Irukayama-Tomode et al. reported GPR109B (HM74) activation by aromatic D-amino acids but not niacin, and expression by of GPR109B mRNA by human neutrophils, but they did not directly demonstrate GPR109B-mediated leukocyte chemotaxis of primary leukocytes (56). Liu et al. demonstrated differential G protein coupling of the C-terminus tails of the HCA2 and HCA3 in yeast (89) but a clearly differentiated physiological role for the GPR109B receptor over its GPR109A neighbour has yet to emerge (119).

\subsection{GPR81 / HCA1 / HCAR1}

The GPR81 lactate receptor is closely related in amino acid sequence to the GPR109A receptor and is expressed predominantly in adipocytes $(18,38)$. Lactate signaling in WAT via the GPR81 receptor decreases lipolysis. A recent study by Sakurai et al identified a series of novel GPR81 agonists that can suppress lipolysis in differentiated 3T3-L1 adipocytes and explanted WAT. These GPR81 agonists can reduce lipolysis in vivo without flushing when 
administered intraperitoneally in mice (162). Lactate is known to exert anti-inflammatory effects on murine macrophages in vitro but these effects were shown to be independent of the murine GPR81 receptor by using bone marrow derived macrophages from wild-type and Gpr81-/- mice (31). At first sight this study seems somewhat at odds with a previous report showing that intraperitoneal delivery of both anti GPR81 siRNA and lactate reduced LPS induced hepatitis and pancreatitis $(50,83)$. One explanation for this discrepancy may lie in the use of siRNA knockdown technology rather than genetic knockout of the Gpr81 gene. It is important to note that not all the physiological effects of lactate are mediated by GPR81 so it will be important to use cell type specific GPR81 knockout animals and GPR81 selective agonists and antagonists in pre-clinical models of inflammation before extending studies into human (patho) physiology.

\section{Important questions and future challenges}

GPCRs were well known to have important roles in endocrine and metabolic functions but recent research has highlighted their importance in inducing or balancing inflammatory and immune responses. Thus select GPCRs are emerging as important players in the new field of immunometabolism. In this section, we present a list of questions to be addressed by the immunometabolism research community over the next 5 to 10 years and we identify current technical hurdles that limit our understanding of immunometabolic GPCR signalling in inflammation and oxidative stress. We need a better understanding of the basic science of this class of signalling receptors to enable access to a wider range of highly selective bioavailable small molecule tool compounds, to improve drug development and inform clinical trial design.

\section{DRG TO COMPLETE}

\section{Are all cells of the innate and adaptive immune response subject to} immunometabolic control? RNA expression data for the GPCRs reviewed here suggests higher mRNA expression in innate immune cells compared to adaptive immune cells. Furthermore, innate immune cell gene expression can be further enhanced by inflammatory cytokines and TLR ligands (ImmGen Consortium and Carlota Recio et al., unpublished data). However, it is not enough to measure relative mRNA abundance. There is a pressing need to develop specific antibody reagents to unambiguously detect cell surface expression of all the 
GPCRs we have reviewed here. Just looking at mRNA expression levels or detecting fluorescent transgene expression cannot be relied upon to identify cells that are capable of responding to specific metabolites via GPCRs.

\section{Can metabolites working through the GPCRs reviewed here significantly affect} macrophage differentiation and macrophage function in vivo? It will be important to critically assess macrophage biology in a range of different tissues, including adipose tissues and atherosclerotic lesions. An area that remains almost completely unexplored remains the effect of metabolites on microglial cell biology. A recent publication reported effects of microbiota and plasma acetate levels on murine microglia morphology but important functional consequences of SCFA receptor activation in the central nervous system remain to be demonstrated and could be very important in developmental (e.g autism) and degenerative (e.g. Alzheimer's) neurological disease.

4. Immunometabolism is clearly linked to changes in diet and microbiota composition and this raises the important question - Can dietary manipulation in humans drive useful changes in innate and adaptive immune responses? Current advice to switch to a diet containing more fibre is unlikely to cause harm but exactly how does the combination of a diet rich in fibre and a 'healthy' microbiota result in less 'low grade' inflammation and a 'healthier' immune response. It is possible that we can accelerate or stabilise these changes using allosteric agonists active at immunometabolic receptors. It is interesting to note that many of the compounds active at the FFARs are ago-allosteric modulators (101).

\section{Can we develop a wider range of metabolic sensing GPCR tool compounds with} drug-like properties? New tool compounds could be used to critically assess the role of candidate GPCRs in metabolic disease and chronic inflammation processes in vitro and in vivo. Some of the GPCRs we have discussed here (e.g. GPR120) have been the subject of multiple commercial drug development programmes but details of the studies performed are largely unpublished and access to useful tool compounds is limited. For other GPCRs (e.g. GPR84) there are only a very limited number of structurally distinct tool compounds known (see Figure 4) and few if any antagonists or partial agonists are available in the public domain. A range of tool compounds that display biased agonism would allow us to test the full range of specific GPCR signalling modalities. GPR84 also illustrates a potentially common theme for all the GPCRs discussed in this review, do we really know what the physiologically relevant agonists are at these immunometabolic receptors? 


\section{Do metabolite sensing GPCRs mediate leukocyte homing and chemotaxis in vivo?}

Of note, most of the immunometabolic GPCRs we have discussed are Gai coupled receptors and this is suggestive of a role in leukocyte migration. There are hints in the published literature that metabolites or immunometabolic receptors such as GPR109A can modulate monocyte / macrophage recruitment in vivo. The development of cell type specific GPCR knockout animals will be very useful to test the hypothesis that metabolites, signalling via specific GPCRs, can act as important leukocyte chemoattractants in vivo.

In summary the family of GPCRs that signal in response to endogenous metabolites and/or microbial fermentation products represent a fascinating entry point into the world of immunometabolism. Over the next 5 years the development of new transgenic mice, receptorspecific monoclonal antibodies and a comprehensive panel of GPCR tool compounds will allow us to identify which of these receptors play a non-redundant role in regulating host immunity and host metabolism in health and disease.

\section{DRG TO COMPLETE}

\section{Abbreviations used}

6-OAU6-n-octylaminouracil

ABCA1 ATP-binding cassette transporter A1

ALA $\quad \alpha$-linolenic acid

AOX azoxymetane

cAMP cyclic AMP

CETP cholesterol ester transfer protein

CLA conjugated linoleic acid

DAG diacylglycerol

DBA Dilute Brown Non-Agouti 


\begin{tabular}{|c|c|}
\hline DHA & docosahexaenoic acid \\
\hline DIM & diindolylmethane \\
\hline DP1 & prostaglandin D2 receptor 1 \\
\hline DSS & dextran sulphate sodium \\
\hline Duox & dual oxidases \\
\hline EAE & experimental autoimmune encephalomyelitis \\
\hline EPA & eicosapentaenoic acid \\
\hline ER & endoplasmic reticulum \\
\hline FFA & free fatty acid \\
\hline GIP & gastric inhibitory polypeptide \\
\hline GLP-1 & glucagon-like peptide-1 \\
\hline GPCR & $\mathrm{G}$ protein-coupled receptor \\
\hline GSHPx & glutathione peroxidase \\
\hline HFD & high fat diet \\
\hline IBD & inflammatory bowel disease \\
\hline IL & interleukin \\
\hline IP3 & inositol triphosphate \\
\hline IR & insulin receptor \\
\hline LCFA & long chain fatty acid \\
\hline LDL & low-density lipoprotein \\
\hline LPS & lipopolysaccharide \\
\hline MCFA & medium chain fatty acid \\
\hline MMF & monomethylfumerate \\
\hline
\end{tabular}


MMP-9 metalloproteinase-9

mRNA messenger RNA

NA nicotinic acid

$\mathrm{NAD}(\mathrm{P}) \mathrm{H}$ nicotinamide adenine dinucleotide phosphate

NFkB nuclear factor kappa-light-chain-enhancer of activated B cells

NOX NAD(P)H oxidase

PIP2 phosphatidylinositol 4,5-bisphosphate

PKC protein kinase $\mathrm{C}$

PMN polymorphonuclear

PPAR $\gamma \quad$ peroxisome proliferator activated receptor gamma

PSCK9 proprotein convertase subtilisin/kexin type9

PYY peptide YY

ROS reactive oxygen species

SCFA short chain fatty acid

SOD $\quad$ superoxide dismutase

T2D type 2 diabetes

TG triglyceride

TLR4 toll like receptor-4

TNF- $\alpha \quad$ tumour necrosis factor- $\alpha$

WAT white adipose tissue

$\omega 3-P U F A \quad$ omega-3 fatty acid 
Work in our laboratories in Oxford is supported by Novo Nordisk Foundation grant number NNF15CC0018346 and the Tripartite Immunometabolism Consortium [TrIC]- Novo Nordisk Foundation grant number NNF15CC0018486. Work in the Greaves laboratory is supported by a British Heart Foundation (BHF) programme grant RG/15/10/23915. DRG and AJR acknowledge support from the BHF Centre of Research Excellence, Oxford (RE/13/1/30181).

\section{Figure and Table Legends}

Table 1. Metabolite-sensing GPCRs involved in immunometabolic signalling

Figure 1. Illustrative flowchart that represents the role that inflammation and oxidative stress play in metabolic disease.

Activation of intracellular signalling pathways aggravates the inflammatory process leading to severe consequences such as insulin resistance (T2D) and increased risk of CVD.

Figure 2. General structure of GPCRs. Top left: the snake diagram shows the seven transmembrane domains with the extracellular $\mathrm{N}$-terminus and the $\mathrm{C}$-terminus located inside the cell. Top right: proposed molecular structure of a GPCR in complex with G $\alpha \beta \gamma$ (taken from the studies of Brian Kobilka and Robert Lefkowitz in GPCRs that gave them the Nobel Prize in Chemistry in 2012 (9)). The representation shows the seven transmembrane helices which are arranged in an approximately circular fashion within the membrane plane. The yellow structure represents the GPCR ligand within the binding site which is in the middle of the helices, being accessible from the extracellular side. Bottom panel: different G protein coupling of the metabolite sensing GPCRs included in this review.

Figure 3. Proposed mechanism of action of long-chain fatty acid receptors (GPR120 and GPR40) in different cell types. 
Top left panel: Both GPR40 and GPR120 are expressed in immune cells and signal via different intracellular cascades including TLR4, TNFa, JNK and IKK involved in inflammation and migration. Top middle panel: LCFA-induced GPR120 signaling elicits adipogenesis and increased glucose uptake in adipose tissue. Top right panel: GPR40 and GPR120 regulate the secretion of GLP-1 in enteroendocrine cells. Bottom left panel: In pancreatic cells, both GPR40 and GPR120 promote LCFA-mediated insulin secretion. Bottom right panel: GPR40 is expressed in neurons exerting a neuroprotective role and decreasing nociception.

Figure 4. Chemical structures of reported GPR84 physiological agonists and GPR84 tool compounds.

Figure 5. SCFA receptor GPR43 proposed mechanism of action in neutrophils.

SCFA-induced GPR43 signaling elicits chemotaxis and increased inflammatory profile in neutrophils by activating different intracellular signalling pathways including MAPK kinases, ERK and $\mathrm{p} 38$.

Figure 6. Succinate receptor proposed mechanism of action.

Succinate-mediated GPR91 signalling (red arrows) activates inflammatory cascades in macrophages that lead to tissue inflammation. GPR91-driven increased glycolysis (blue arrows) promotes the synthesis of succinate that exerts both autocrine effects in macrophages and paracrine effects on neighbouring cells. Modified from Littlewood-Evans et al. (86).

Figure 7. Niacin receptors mechanism of action.

Left part: In adipocytes, nicotinic acid binds niacin receptors leading to a decrease in free fatty acids mobilization from adipose tissue to the liver resulting in a reduction of TG and thus LDL and VLDL synthesis. Right part: In macrophages and microglia, niacin receptor- 
mediated signalling induces antioxidant and neuroprotective effects and reduces inflammation.

\section{References}

1. Ahmed K, Tunaru S, Offermanns S. GPR109A, GPR109B and GPR81, a family of hydroxy-carboxylic acid receptors. Trends Pharmacol Sci 30: 557-62, 2009.

2. Alfonzo-Mendez MA, Alcantara-Hernandez R, Garcia-Sainz JA. Novel Structural Approaches to Study GPCR Regulation. Int J Mol Sci 18, 2016.

3. Alvarez-Curto E, Milligan G. Metabolism meets immunity: The role of free fatty acid receptors in the immune system. Biochem Pharmacol 114: 3-13, 2016.

4. Ang Z, Ding JL. GPR41 and GPR43 in Obesity and Inflammation - Protective or Causative? Front Immunol 7: 28, 2016.

5. Ang Z, Er JZ, Ding JL. The short-chain fatty acid receptor GPR43 is transcriptionally regulated by XBP1 in human monocytes. Sci Rep 5: 8134, 2015.

6. Araki E, Nishikawa T. Oxidative stress: A cause and therapeutic target of diabetic complications. J Diabetes Investig 1: 90-6, 2010.

7. Atta-ur-Rahman MIC. Anti-Obesity Drug Discovery and Development. 2014.

8. Audoy-Remus J, Bozoyan L, Dumas A, Filali M, Lecours C, Lacroix S, Rivest S, Tremblay ME, Vallieres L. GPR84 deficiency reduces microgliosis, but accelerates dendritic degeneration and cognitive decline in a mouse model of Alzheimer's disease. Brain Behav Immun 46: 112-20, 2015.

9. Benovic JL. G-protein-coupled receptors signal victory. Cell 151: 1148-50, 2012.

10. Benyo Z, Gille A, Bennett CL, Clausen BE, Offermanns S. Nicotinic acid-induced flushing is mediated by activation of epidermal langerhans cells. Mol Pharmacol 70: 1844-9, 2006.

11. Benyo Z, Gille A, Kero J, Csiky M, Suchankova MC, Nusing RM, Moers A, Pfeffer K, Offermanns S. GPR109A (PUMA-G/HM74A) mediates nicotinic acid-induced flushing. J Clin Invest 115: 3634-40, 2005. 
12. Bhuniya D, Umrani D, Dave B, Salunke D, Kukreja G, Gundu J, Naykodi M, Shaikh NS, Shitole P, Kurhade S, De S, Majumdar S, Reddy SB, Tambe S, Shejul Y, Chugh A, Palle VP, Mookhtiar KA, Cully D, Vacca J, Chakravarty PK, Nargund RP, Wright SD, Graziano MP, Singh SB, Roy S, Cai TQ. Discovery of a potent and selective small molecule hGPR91 antagonist. Bioorg Med Chem Lett 21: 3596-602, 2011.

13. Bjursell M, Admyre T, Goransson M, Marley AE, Smith DM, Oscarsson J, Bohlooly YM. Improved glucose control and reduced body fat mass in free fatty acid receptor 2-deficient mice fed a high-fat diet. Am J Physiol Endocrinol Metab 300: E211-20, 2011.

14. Blad CC, Tang C, Offermanns S. G protein-coupled receptors for energy metabolites as new therapeutic targets. Nat Rev Drug Discov 11: 603-19, 2012.

15. Boren J, Williams KJ. The central role of arterial retention of cholesterol-rich apolipoprotein-B-containing lipoproteins in the pathogenesis of atherosclerosis: a triumph of simplicity. Curr Opin Lipidol 27: 473-83, 2016.

16. Briscoe CP, Tadayyon M, Andrews JL, Benson WG, Chambers JK, Eilert MM, Ellis C, Elshourbagy NA, Goetz AS, Minnick DT, Murdock PR, Sauls HR, Jr., Shabon U, Spinage LD, Strum JC, Szekeres PG, Tan KB, Way JM, Ignar DM, Wilson S, Muir AI. The orphan G protein-coupled receptor GPR40 is activated by medium and long chain fatty acids. J Biol Chem 278: 11303-11, 2003.

17. Brown AJ, Goldsworthy SM, Barnes AA, Eilert MM, Tcheang L, Daniels D, Muir AI, Wigglesworth MJ, Kinghorn I, Fraser NJ, Pike NB, Strum JC, Steplewski KM, Murdock PR, Holder JC, Marshall FH, Szekeres PG, Wilson S, Ignar DM, Foord SM, Wise A, Dowell SJ. The Orphan G protein-coupled receptors GPR41 and GPR43 are activated by propionate and other short chain carboxylic acids. J Biol Chem 278: 11312-9, 2003.

18. Cai TQ, Ren N, Jin L, Cheng K, Kash S, Chen R, Wright SD, Taggart AK, Waters MG. Role of GPR81 in lactate-mediated reduction of adipose lipolysis. Biochem Biophys Res Commun 377: 987-91, 2008.

19. Canner PL, Berge KG, Wenger NK, Stamler J, Friedman L, Prineas RJ, Friedewald W. Fifteen year mortality in Coronary Drug Project patients: long-term benefit with niacin. J Am Coll Cardiol 8: 1245-55, 1986.

20. Carlson LA. Nicotinic acid: the broad-spectrum lipid drug. A 50th anniversary review. J Intern Med 258: 94-114, 2005. 
21. Cartoni C, Yasumatsu K, Ohkuri T, Shigemura N, Yoshida R, Godinot N, le Coutre J, Ninomiya Y, Damak S. Taste preference for fatty acids is mediated by GPR40 and GPR120. J Neurosci 30: 8376-82, 2010.

22. Chawla A, Nguyen KD, Goh YP. Macrophage-mediated inflammation in metabolic disease. Nat Rev Immunol 11: 738-49, 2011.

23. Correa PR, Kruglov EA, Thompson M, Leite MF, Dranoff JA, Nathanson MH. Succinate is a paracrine signal for liver damage. J Hepatol 47: 262-9, 2007.

24. Dandona P, Aljada A, Bandyopadhyay A. Inflammation: the link between insulin resistance, obesity and diabetes. Trends Immunol 25: 4-7, 2004.

25. Dandona P, Thusu K, Cook S, Snyder B, Makowski J, Armstrong D, Nicotera T. Oxidative damage to DNA in diabetes mellitus. Lancet 347: 444-5, 1996.

26. Defossa E, Wagner M. Recent developments in the discovery of FFA1 receptor agonists as novel oral treatment for type 2 diabetes mellitus. Bioorg Med Chem Lett 24: 2991-3000, 2014.

27. Dunbar RL, Gelfand JM. Seeing red: flushing out instigators of niacin-associated skin toxicity. J Clin Invest 120: 2651-5, 2010.

28. Edfalk S, Steneberg P, Edlund H. Gpr40 is expressed in enteroendocrine cells and mediates free fatty acid stimulation of incretin secretion. Diabetes 57: 2280-7, 2008.

29. Eizirik DL, Colli ML, Ortis F. The role of inflammation in insulitis and beta-cell loss in type 1 diabetes. Nat Rev Endocrinol 5: 219-26, 2009.

30. El-Ashmawy NE, Khedr EG, El-Bahrawy HA, Al-Tantawy SM. Chemopreventive effect of omega-3 polyunsaturated fatty acids and atorvastatin in rats with bladder cancer. Tumour Biol 39: 1010428317692254, 2017.

31. Errea A, Cayet D, Marchetti P, Tang C, Kluza J, Offermanns S, Sirard JC, Rumbo M. Lactate Inhibits the Pro-Inflammatory Response and Metabolic Reprogramming in Murine Macrophages in a GPR81-Independent Manner. PLoS One 11: e0163694, 2016.

32. Fiala M, Kooij G, Wagner K, Hammock B, Pellegrini M. Modulation of innate immunity of patients with Alzheimer's disease by omega-3 fatty acids. Faseb j, 2017.

33. Fitzgerald K, White S, Borodovsky A, Bettencourt BR, Strahs A, Clausen V, Wijngaard P, Horton JD, Taubel J, Brooks A, Fernando C, Kauffman RS, Kallend D, Vaishnaw A, Simon A. A Highly Durable RNAi Therapeutic Inhibitor of PCSK9. $N$ Engl J Med 376: 41-51, 2017. 
34. Fredriksson R, Hoglund PJ, Gloriam DE, Lagerstrom MC, Schioth HB. Seven evolutionarily conserved human rhodopsin $\mathrm{G}$ protein-coupled receptors lacking close relatives. FEBS Lett 554: 381-8, 2003.

35. Fredriksson R, Schioth HB. The repertoire of G-protein-coupled receptors in fully sequenced genomes. Mol Pharmacol 67: 1414-25, 2005.

36. Fujiwara K, Maekawa F, Yada T. Oleic acid interacts with GPR40 to induce Ca2+ signaling in rat islet beta-cells: mediation by PLC and L-type Ca2+ channel and link to insulin release. Am J Physiol Endocrinol Metab 289: E670-7, 2005.

37. Ge H, Li X, Weiszmann J, Wang P, Baribault H, Chen JL, Tian H, Li Y. Activation of $\mathrm{G}$ protein-coupled receptor 43 in adipocytes leads to inhibition of lipolysis and suppression of plasma free fatty acids. Endocrinology 149: 4519-26, 2008.

38. Ge H, Weiszmann J, Reagan JD, Gupte J, Baribault H, Gyuris T, Chen JL, Tian H, Li Y. Elucidation of signaling and functional activities of an orphan GPCR, GPR81. $J$ Lipid Res 49: 797-803, 2008.

39. Gether U. Uncovering molecular mechanisms involved in activation of $\mathrm{G}$ proteincoupled receptors. Endocr Rev 21: 90-113, 2000.

40. Graciano MF, Valle MM, Kowluru A, Curi R, Carpinelli AR. Regulation of insulin secretion and reactive oxygen species production by free fatty acids in pancreatic islets. Islets 3: 213-23, 2011.

41. Granier S, Kobilka B. A new era of GPCR structural and chemical biology. Nat Chem Biol 8: 670-3, 2012.

42. Hakak Y, Lehmann-Bruinsma K, Phillips S, Le T, Liaw C, Connolly DT, Behan DP. The role of the GPR91 ligand succinate in hematopoiesis. J Leukoc Biol 85: 837-43, 2009.

43. Hamel D, Sanchez M, Duhamel F, Roy O, Honore JC, Noueihed B, Zhou T, NadeauVallee M, Hou X, Lavoie JC, Mitchell G, Mamer OA, Chemtob S. G-protein-coupled receptor 91 and succinate are key contributors in neonatal postcerebral hypoxiaischemia recovery. Arterioscler Thromb Vasc Biol 34: 285-93, 2014.

44. Hanefeld M, Pistrosch F, Bornstein SR, Birkenfeld AL. The metabolic vascular syndrome - guide to an individualized treatment. Rev Endocr Metab Disord 17: 5-17, 2016.

45. Hanson J, Gille A, Zwykiel S, Lukasova M, Clausen BE, Ahmed K, Tunaru S, Wirth A, Offermanns S. Nicotinic acid- and monomethyl fumarate-induced flushing 
involves GPR109A expressed by keratinocytes and COX-2-dependent prostanoid formation in mice. J Clin Invest 120: 2910-9, 2010.

46. Hara T, Hirasawa A, Ichimura A, Kimura I, Tsujimoto G. Free fatty acid receptors FFAR1 and GPR120 as novel therapeutic targets for metabolic disorders. J Pharm Sci 100: 3594-601, 2011.

47. He W, Miao FJ, Lin DC, Schwandner RT, Wang Z, Gao J, Chen JL, Tian H, Ling L. Citric acid cycle intermediates as ligands for orphan G-protein-coupled receptors. Nature 429: 188-93, 2004.

48. Hirasawa A, Tsumaya K, Awaji T, Katsuma S, Adachi T, Yamada M, Sugimoto Y, Miyazaki S, Tsujimoto G. Free fatty acids regulate gut incretin glucagon-like peptide1 secretion through GPR120. Nat Med 11: 90-4, 2005.

49. Hong YH, Nishimura Y, Hishikawa D, Tsuzuki H, Miyahara H, Gotoh C, Choi KC, Feng DD, Chen C, Lee HG, Katoh K, Roh SG, Sasaki S. Acetate and propionate short chain fatty acids stimulate adipogenesis via GPCR43. Endocrinology 146: 5092-9, 2005.

50. Hoque R, Farooq A, Ghani A, Gorelick F, Mehal WZ. Lactate reduces liver and pancreatic injury in Toll-like receptor- and inflammasome-mediated inflammation via GPR81-mediated suppression of innate immunity. Gastroenterology 146: 1763-74, 2014.

51. Hotamisligil GS. Inflammation and metabolic disorders. Nature 444: 860-867, 2006.

52. Hotamisligil GS, Shargill NS, Spiegelman BM. Adipose expression of tumor necrosis factor-alpha: direct role in obesity-linked insulin resistance. Science 259: 87-91, 1993.

53. Huang W, Guo HL, Deng X, Zhu TT, Xiong JF, Xu YH, Xu Y. Short-Chain Fatty Acids Inhibit Oxidative Stress and Inflammation in Mesangial Cells Induced by High Glucose and Lipopolysaccharide. Exp Clin Endocrinol Diabetes 125: 98-105, 2017.

54. Husted AS, Trauelsen M, Rudenko O, Hjorth SA, Schwartz TW. GPCR-Mediated Signaling of Metabolites. Cell Metab 25: 777-796, 2017.

55. Ichimura A, Hirasawa A, Poulain-Godefroy O, Bonnefond A, Hara T, Yengo L, Kimura I, Leloire A, Liu N, Iida K, Choquet H, Besnard P, Lecoeur C, Vivequin S, Ayukawa K, Takeuchi M, Ozawa K, Tauber M, Maffeis C, Morandi A, Buzzetti R, Elliott P, Pouta A, Jarvelin MR, Korner A, Kiess W, Pigeyre M, Caiazzo R, Van Hul W, Van Gaal L, Horber F, Balkau B, Levy-Marchal C, Rouskas K, Kouvatsi A, Hebebrand J, Hinney A, Scherag A, Pattou F, Meyre D, Koshimizu TA, Wolowczuk 
I, Tsujimoto G, Froguel P. Dysfunction of lipid sensor GPR120 leads to obesity in both mouse and human. Nature 483: 350-4, 2012.

56. Irukayama-Tomobe Y, Tanaka H, Yokomizo T, Hashidate-Yoshida T, Yanagisawa M, Sakurai T. Aromatic D-amino acids act as chemoattractant factors for human leukocytes through a G protein-coupled receptor, GPR109B. Proc Natl Acad Sci U S A 106: 3930-4, 2009.

57. Itoh Y, Kawamata Y, Harada M, Kobayashi M, Fujii R, Fukusumi S, Ogi K, Hosoya M, Tanaka Y, Uejima H, Tanaka H, Maruyama M, Satoh R, Okubo S, Kizawa H, Komatsu H, Matsumura F, Noguchi Y, Shinohara T, Hinuma S, Fujisawa Y, Fujino M. Free fatty acids regulate insulin secretion from pancreatic beta cells through GPR40. Nature 422: 173-6, 2003.

58. Jackson MJ, Papa S, Bolanos J, Bruckdorfer R, Carlsen H, Elliott RM, Flier J, Griffiths HR, Heales S, Holst B, Lorusso M, Lund E, Oivind Moskaug J, Moser U, Di Paola M, Polidori MC, Signorile A, Stahl W, Vina-Ribes J, Astley SB. Antioxidants, reactive oxygen and nitrogen species, gene induction and mitochondrial function. $\mathrm{Mol}$ Aspects Med 23: 209-85, 2002.

59. Kaku K, Araki T, Yoshinaka R. Randomized, double-blind, dose-ranging study of TAK-875, a novel GPR40 agonist, in Japanese patients with inadequately controlled type 2 diabetes. Diabetes Care 36: 245-50, 2013.

60. Kalupahana NS, Moustaid-Moussa N, Claycombe KJ. Immunity as a link between obesity and insulin resistance. Mol Aspects Med 33: 26-34, 2012.

61. Kamp ME, Shim R, Nicholls AJ, Oliveira AC, Mason LJ, Binge L, Mackay CR, Wong CH. G Protein-Coupled Receptor 43 Modulates Neutrophil Recruitment during Acute Inflammation. PLoS One 11: e0163750, 2016.

62. Karaki S, Mitsui R, Hayashi H, Kato I, Sugiya H, Iwanaga T, Furness JB, Kuwahara A. Short-chain fatty acid receptor, GPR43, is expressed by enteroendocrine cells and mucosal mast cells in rat intestine. Cell Tissue Res 324: 353-60, 2006.

63. Karaki S, Tazoe H, Hayashi H, Kashiwabara H, Tooyama K, Suzuki Y, Kuwahara A. Expression of the short-chain fatty acid receptor, GPR43, in the human colon. $J$ Mol Histol 39: 135-42, 2008.

64. Karki P, Kurihara T, Nakamachi T, Watanabe J, Asada T, Oyoshi T, Shioda S, Yoshimura M, Arita K, Miyata A. Attenuation of inflammatory and neuropathic pain behaviors in mice through activation of free fatty acid receptor GPR40. Mol Pain 11: $6,2015$. 
65. Kayama Y, Raaz U, Jagger A, Adam M, Schellinger IN, Sakamoto M, Suzuki H, Toyama K, Spin JM, Tsao PS. Diabetic Cardiovascular Disease Induced by Oxidative Stress. Int J Mol Sci 16: 25234-63, 2015.

66. Keane KN, Cruzat VF, Carlessi R, de Bittencourt PI, Jr., Newsholme P. Molecular Events Linking Oxidative Stress and Inflammation to Insulin Resistance and beta-Cell Dysfunction. Oxid Med Cell Longev 2015: 181643, 2015.

67. Keaney JF, Jr., Larson MG, Vasan RS, Wilson PW, Lipinska I, Corey D, Massaro JM, Sutherland P, Vita JA, Benjamin EJ. Obesity and systemic oxidative stress: clinical correlates of oxidative stress in the Framingham Study. Arterioscler Thromb Vasc Biol 23: 434-9, 2003.

68. Kelly AS, Ryder JR, Marlatt KL, Rudser KD, Jenkins T, Inge TH. Changes in inflammation, oxidative stress and adipokines following bariatric surgery among adolescents with severe obesity. Int J Obes (Lond) 40: 275-80, 2016.

69. Kelly B, O'Neill LA. Metabolic reprogramming in macrophages and dendritic cells in innate immunity. Cell Res 25: 771-84, 2015.

70. Kim MH, Kang SG, Park JH, Yanagisawa M, Kim CH. Short-chain fatty acids activate GPR41 and GPR43 on intestinal epithelial cells to promote inflammatory responses in mice. Gastroenterology 145: 396-406.e1-10, 2013.

71. Kim S, Hwang J, Xuan J, Jung YH, Cha HS, Kim KH. Global metabolite profiling of synovial fluid for the specific diagnosis of rheumatoid arthritis from other inflammatory arthritis. PLoS One 9: e97501, 2014.

72. Kim S, Kim JH, Park BO, Kwak YS. Perspectives on the therapeutic potential of short-chain fatty acid receptors. BMB Rep 47: 173-8, 2014.

73. Kimura I, Ozawa K, Inoue D, Imamura T, Kimura K, Maeda T, Terasawa K, Kashihara D, Hirano K, Tani T, Takahashi T, Miyauchi S, Shioi G, Inoue H, Tsujimoto G. The gut microbiota suppresses insulin-mediated fat accumulation via the short-chain fatty acid receptor GPR43. Nat Commun 4: 1829, 2013.

74. Knowles HJ, te Poele RH, Workman P, Harris AL. Niacin induces PPARgamma expression and transcriptional activation in macrophages via HM74 and HM74amediated induction of prostaglandin synthesis pathways. Biochem Pharmacol 71: 646-56, 2006.

75. Kowaltowski AJ, de Souza-Pinto NC, Castilho RF, Vercesi AE. Mitochondria and reactive oxygen species. Free Radic Biol Med 47: 333-43, 2009. 
76. Kristinsson H, Bergsten P, Sargsyan E. Free fatty acid receptor 1 (FFAR1/GPR40) signaling affects insulin secretion by enhancing mitochondrial respiration during palmitate exposure. Biochim Biophys Acta 1853: 3248-57, 2015.

77. Lan H, Hoos LM, Liu L, Tetzloff G, Hu W, Abbondanzo SJ, Vassileva G, Gustafson EL, Hedrick JA, Davis HR. Lack of FFAR1/GPR40 does not protect mice from highfat diet-induced metabolic disease. Diabetes 57: 2999-3006, 2008.

78. Landray MJ, Haynes R, Hopewell JC, Parish S, Aung T, Tomson J, Wallendszus K, Craig M, Jiang L, Collins R, Armitage J. Effects of extended-release niacin with laropiprant in high-risk patients. N Engl J Med 371: 203-12, 2014.

79. Lauring B, Taggart AK, Tata JR, Dunbar R, Caro L, Cheng K, Chin J, Colletti SL, Cote J, Khalilieh S, Liu J, Luo WL, Maclean AA, Peterson LB, Polis AB, Sirah W, Wu TJ, Liu X, Jin L, Wu K, Boatman PD, Semple G, Behan DP, Connolly DT, Lai E, Wagner JA, Wright SD, Cuffie C, Mitchel YB, Rader DJ, Paolini JF, Waters MG, Plump A. Niacin lipid efficacy is independent of both the niacin receptor GPR109A and free fatty acid suppression. Sci Transl Med 4: 148ra115, 2012.

80. Le Poul E, Loison C, Struyf S, Springael JY, Lannoy V, Decobecq ME, Brezillon S, Dupriez V, Vassart G, Van Damme J, Parmentier M, Detheux M. Functional characterization of human receptors for short chain fatty acids and their role in polymorphonuclear cell activation. J Biol Chem 278: 25481-9, 2003.

81. Lee SU, In HJ, Kwon MS, Park BO, Jo M, Kim MO, Cho S, Lee S, Lee HJ, Kwak YS, Kim S. beta-Arrestin 2 mediates G protein-coupled receptor 43 signals to nuclear factor-kappaB. Biol Pharm Bull 36: 1754-9, 2013.

82. Leifke E, Naik H, Wu J, Viswanathan P, Demanno D, Kipnes M, Vakilynejad M. A multiple-ascending-dose study to evaluate safety, pharmacokinetics, and pharmacodynamics of a novel GPR40 agonist, TAK-875, in subjects with type 2 diabetes. Clin Pharmacol Ther 92: 29-39, 2012.

83. Lerch MM, Conwell DL, Mayerle J. The anti-inflammasome effect of lactate and the lactate GPR81-receptor in pancreatic and liver inflammation. Gastroenterology 146: 1602-5, 2014.

84. Li YH, Choi DH, Lee EH, Seo SR, Lee S, Cho EH. Sirtuin 3 (SIRT3) Regulates alpha-Smooth Muscle Actin (alpha-SMA) Production through the Succinate Dehydrogenase-G Protein-coupled Receptor 91 (GPR91) Pathway in Hepatic Stellate Cells. J Biol Chem 291: 10277-92, 2016. 
85. Li Z, Qiu Q, Geng X, Yang J, Huang W, Qian H. Free fatty acid receptor agonists for the treatment of type 2 diabetes: drugs in preclinical to phase II clinical development. Expert Opin Investig Drugs 25: 871-90, 2016.

86. Littlewood-Evans A, Sarret S, Apfel V, Loesle P, Dawson J, Zhang J, Muller A, Tigani B, Kneuer R, Patel S, Valeaux S, Gommermann N, Rubic-Schneider T, Junt T, Carballido JM. GPR91 senses extracellular succinate released from inflammatory macrophages and exacerbates rheumatoid arthritis. $J$ Exp Med 213: 1655-62, 2016.

87. Liu HD, Wang WB, Xu ZG, Liu CH, He DF, Du LP, Li MY, Yu X, Sun JP. FFA4 receptor (GPR120): A hot target for the development of anti-diabetic therapies. Eur $J$ Pharmacol 763: 160-8, 2015.

88. Liu Q, Shimoyama T, Suzuki K, Umeda T, Nakaji S, Sugawara K. Effect of sodium butyrate on reactive oxygen species generation by human neutrophils. Scand $J$ Gastroenterol 36: 744-50, 2001.

89. Liu R, van Veldhoven JP, AP IJ. The role of the C-terminus of the human hydroxycarboxylic acid receptors 2 and 3 in $\mathrm{G}$ protein activation using Galphaengineered yeast cells. Eur J Pharmacol 770: 70-7, 2016.

90. Liu Y, Zhang Q, Chen LH, Yang H, Lu W, Xie X, Nan FJ. Design and Synthesis of 2Alkylpyrimidine-4,6-diol and 6-Alkylpyridine-2,4-diol as Potent GPR84 Agonists. ACS Med Chem Lett 7: 579-83, 2016.

91. Lorente-Cebrian S, Costa AG, Navas-Carretero S, Zabala M, Laiglesia LM, Martinez JA, Moreno-Aliaga MJ. An update on the role of omega-3 fatty acids on inflammatory and degenerative diseases. J Physiol Biochem 71: 341-9, 2015.

92. Lukasova M, Malaval C, Gille A, Kero J, Offermanns S. Nicotinic acid inhibits progression of atherosclerosis in mice through its receptor GPR109A expressed by immune cells. J Clin Invest 121: 1163-73, 2011.

93. Ma D, Tao B, Warashina S, Kotani S, Lu L, Kaplamadzhiev DB, Mori Y, Tonchev $\mathrm{AB}$, Yamashima T. Expression of free fatty acid receptor GPR40 in the central nervous system of adult monkeys. Neurosci Res 58: 394-401, 2007.

94. Mancini AD, Poitout V. GPR40 agonists for the treatment of type 2 diabetes: life after 'TAKing' a hit. Diabetes Obes Metab 17: 622-9, 2015.

95. Mandrika I, Petrovska R, Klovins J. Evidence for constitutive dimerization of niacin receptor subtypes. Biochem Biophys Res Commun 395: 281-7, 2010. 
96. Manosalva C, Mena J, Velasquez Z, Colenso CK, Brauchi S, Burgos RA, Hidalgo MA. Cloning, identification and functional characterization of bovine free fatty acid receptor-1 (FFAR1/GPR40) in neutrophils. PLoS One 10: e0119715, 2015.

97. Maslowski KM, Mackay CR. Diet, gut microbiota and immune responses. Nat Immunol 12: 5-9, 2011.

98. Maslowski KM, Vieira AT, Ng A, Kranich J, Sierro F, Yu D, Schilter HC, Rolph MS, Mackay F, Artis D, Xavier RJ, Teixeira MM, Mackay CR. Regulation of inflammatory responses by gut microbiota and chemoattractant receptor GPR43. Nature 461: 1282-6, 2009.

99. Mathis D, Shoelson SE. Immunometabolism: an emerging frontier. Nat Rev Immunol 11: 81, 2011.

100. McNelis JC, Lee YS, Mayoral R, van der Kant R, Johnson AM, Wollam J, Olefsky JM. GPR43 Potentiates beta-Cell Function in Obesity. Diabetes 64: 3203-17, 2015.

101. Milligan G, Shimpukade B, Ulven T, Hudson BD. Complex Pharmacology of Free Fatty Acid Receptors. Chem Rev 117: 67-110, 2017.

102. Mills E, O'Neill LA. Succinate: a metabolic signal in inflammation. Trends Cell Biol 24: 313-20, 2014.

103. Miyamoto J, Hasegawa S, Kasubuchi M, Ichimura A, Nakajima A, Kimura I. Nutritional Signaling via Free Fatty Acid Receptors. Int J Mol Sci 17: 450, 2016.

104. Moniri NH. Free-fatty acid receptor-4 (GPR120): Cellular and molecular function and its role in metabolic disorders. Biochem Pharmacol 110-111: 1-15, 2016.

105. Nadeem A, Ahmad SF, Al-Harbi NO, El-Sherbeeny AM, Al-Harbi MM, Almukhlafi TS. GPR43 activation enhances psoriasis-like inflammation through epidermal upregulation of IL-6 and dual oxidase 2 signaling in a murine model. Cell Signal 33: 59-68, 2017.

106. Nagasumi K, Esaki R, Iwachidow K, Yasuhara Y, Ogi K, Tanaka H, Nakata M, Yano T, Shimakawa K, Taketomi S, Takeuchi K, Odaka H, Kaisho Y. Overexpression of GPR40 in pancreatic beta-cells augments glucose-stimulated insulin secretion and improves glucose tolerance in normal and diabetic mice. Diabetes 58: 1067-76, 2009.

107. Nakamoto K, Aizawa F, Nishinaka T, Tokuyama S. Regulation of prohormone convertase 2 protein expression via GPR40/FFA1 in the hypothalamus. Eur $J$ Pharmacol 762: 459-63, 2015. 
108. Nakamoto K, Nishinaka T, Matsumoto K, Kasuya F, Mankura M, Koyama Y, Tokuyama S. Involvement of the long-chain fatty acid receptor GPR40 as a novel pain regulatory system. Brain Res 1432: 74-83, 2012.

109. Nakamoto K, Nishinaka T, Sato N, Mankura M, Koyama Y, Kasuya F, Tokuyama S. Hypothalamic GPR40 signaling activated by free long chain fatty acids suppresses CFA-induced inflammatory chronic pain. PLoS One 8: e81563, 2013.

110. Nakao S, Moriya Y, Furuyama S, Niederman R, Sugiya H. Propionic acid stimulates superoxide generation in human neutrophils. Cell Biol Int 22: 331-7, 1998.

111. Natalicchio A, Labarbuta R, Tortosa F, Biondi G, Marrano N, Peschechera A, Carchia E, Orlando MR, Leonardini A, Cignarelli A, Marchetti P, Perrini S, Laviola L, Giorgino F. Exendin-4 protects pancreatic beta cells from palmitate-induced apoptosis by interfering with GPR40 and the MKK4/7 stress kinase signalling pathway. Diabetologia 56: 2456-66, 2013.

112. Newsholme P, Cruzat VF, Keane KN, Carlessi R, de Bittencourt PI, Jr. Molecular mechanisms of ROS production and oxidative stress in diabetes. Biochem $J$ 473: 4527-4550, 2016.

113. Nicol LS, Dawes JM, La Russa F, Didangelos A, Clark AK, Gentry C, Grist J, Davies JB, Malcangio M, McMahon SB. The role of G-protein receptor 84 in experimental neuropathic pain. J Neurosci 35: 8959-69, 2015.

114. Nilsson NE, Kotarsky K, Owman C, Olde B. Identification of a free fatty acid receptor, FFA2R, expressed on leukocytes and activated by short-chain fatty acids. Biochem Biophys Res Commun 303: 1047-52, 2003.

115. O'Neill LA, Pearce EJ. Immunometabolism governs dendritic cell and macrophage function. J Exp Med 213: 15-23, 2016.

116. O'Neill S, O'Driscoll L. Metabolic syndrome: a closer look at the growing epidemic and its associated pathologies. Obes Rev 16: 1-12, 2015.

117. Odegaard JI, Chawla A. Connecting type 1 and type 2 diabetes through innate immunity. Cold Spring Harb Perspect Med 2: a007724, 2012.

118. Offermanns S. It ain't over 'til the fat lady sings. Sci Transl Med 4: 148fs30, 2012.

119. Offermanns S. Hydroxy-Carboxylic Acid Receptor Actions in Metabolism. Trends Endocrinol Metab 28: 227-236, 2017.

120. Offermanns S, Colletti SL, Lovenberg TW, Semple G, Wise A, AP IJ. International Union of Basic and Clinical Pharmacology. LXXXII: Nomenclature and 
Classification of Hydroxy-carboxylic Acid Receptors (GPR81, GPR109A, and GPR109B). Pharmacol Rev 63: 269-90, 2011.

121. Oh DY, Talukdar S, Bae EJ, Imamura T, Morinaga H, Fan W, Li P, Lu WJ, Watkins SM, Olefsky JM. GPR120 is an omega-3 fatty acid receptor mediating potent antiinflammatory and insulin-sensitizing effects. Cell 142: 687-98, 2010.

122. Organization TWH. 2016. Obesity and overweight. http://www.who.int/mediacentre/factsheets/fs311/en/.

123. Ouchi N, Parker JL, Lugus JJ, Walsh K. Adipokines in inflammation and metabolic disease. Nat Rev Immunol 11: 85-97, 2011.

124. Paerregaard SI, Agerholm M, Serup AK, Ma T, Kiens B, Madsen L, Kristiansen K, Jensen BA. FFAR4 (GPR120) Signaling Is Not Required for Anti-Inflammatory and Insulin-Sensitizing Effects of Omega-3 Fatty Acids. Mediators Inflamm 2016: 1536047, 2016.

125. Patterson CC, Dahlquist GG, Gyurus E, Green A, Soltesz G. Incidence trends for childhood type 1 diabetes in Europe during 1989-2003 and predicted new cases 200520: a multicentre prospective registration study. Lancet 373: 2027-33, 2009.

126. Potter M, Newport E, Morten KJ. The Warburg effect: 80 years on. Biochem Soc Trans 44: 1499-1505, 2016.

127. Quinn MT, Gauss KA. Structure and regulation of the neutrophil respiratory burst oxidase: comparison with nonphagocyte oxidases. J Leukoc Biol 76: 760-81, 2004.

128. Rains JL, Jain SK. Oxidative stress, insulin signaling, and diabetes. Free Radic Biol Med 50: 567-75, 2011.

129. Ramalingam L, Menikdiwela K, LeMieux M, Dufour JM, Kaur G, Kalupahana N, Moustaid-Moussa N. The renin angiotensin system, oxidative stress and mitochondrial function in obesity and insulin resistance. Biochim Biophys Acta, 2016.

130. Regard JB, Sato IT, Coughlin SR. Anatomical profiling of G protein-coupled receptor expression. Cell 135: 561-71, 2008.

131. Rubic T, Lametschwandtner G, Jost S, Hinteregger S, Kund J, Carballido-Perrig N, Schwarzler C, Junt T, Voshol H, Meingassner JG, Mao X, Werner G, Rot A, Carballido JM. Triggering the succinate receptor GPR91 on dendritic cells enhances immunity. Nat Immunol 9: 1261-9, 2008.

132. Rubic T, Trottmann M, Lorenz RL. Stimulation of CD36 and the key effector of reverse cholesterol transport ATP-binding cassette A1 in monocytoid cells by niacin. Biochem Pharmacol 67: 411-9, 2004. 
133. Samuel BS, Shaito A, Motoike T, Rey FE, Backhed F, Manchester JK, Hammer RE, Williams SC, Crowley J, Yanagisawa M, Gordon JI. Effects of the gut microbiota on host adiposity are modulated by the short-chain fatty-acid binding $\mathrm{G}$ protein-coupled receptor, Gpr41. Proc Natl Acad Sci U S A 105: 16767-72, 2008.

134. Sandoval A, Trivinos F, Sanhueza A, Carretta D, Hidalgo MA, Hancke JL, Burgos RA. Propionate induces pH(i) changes through calcium flux, ERK1/2, p38, and PKC in bovine neutrophils. Vet Immunol Immunopathol 115: 286-98, 2007.

135. Sapieha P, Sirinyan M, Hamel D, Zaniolo K, Joyal JS, Cho JH, Honore JC, Kermorvant-Duchemin E, Varma DR, Tremblay S, Leduc M, Rihakova L, Hardy P, Klein WH, Mu X, Mamer O, Lachapelle P, Di Polo A, Beausejour C, Andelfinger G, Mitchell G, Sennlaub F, Chemtob S. The succinate receptor GPR91 in neurons has a major role in retinal angiogenesis. Nat Med 14: 1067-76, 2008.

136. Sartorius T, Drescher A, Panse M, Lastovicka P, Peter A, Weigert C, Kostenis E, Ullrich S, Haring HU. Mice Lacking Free Fatty Acid Receptor 1 (GPR40/FFAR1) are Protected Against Conjugated Linoleic Acid-Induced Fatty Liver but Develop Inflammation and Insulin Resistance in the Brain. Cell Physiol Biochem 35: 2272-84, 2015.

137. Sawzdargo M, George SR, Nguyen T, Xu S, Kolakowski LF, O'Dowd BF. A cluster of four novel human $\mathrm{G}$ protein-coupled receptor genes occurring in close proximity to CD22 gene on chromosome 19q13.1. Biochem Biophys Res Commun 239: 543-7, 1997.

138. Schenk S, Saberi M, Olefsky JM. Insulin sensitivity: modulation by nutrients and inflammation. J Clin Invest 118: 2992-3002, 2008.

139. Schmidt J, Liebscher K, Merten N, Grundmann M, Mielenz M, Sauerwein H, Christiansen E, Due-Hansen ME, Ulven T, Ullrich S, Gomeza J, Drewke C, Kostenis E. Conjugated linoleic acids mediate insulin release through islet $\mathrm{G}$ protein-coupled receptor FFA1/GPR40. J Biol Chem 286: 11890-4, 2011.

140. Sekiguchi H, Kasubuchi M, Hasegawa S, Pelisch N, Kimura I, Ichimura A. A novel antidiabetic therapy: free fatty acid receptors as potential drug target. Curr Diabetes Rev 11: 107-15, 2015.

141. Senga T, Iwamoto S, Yoshida T, Yokota T, Adachi K, Azuma E, Hamaguchi M, Iwamoto T. LSSIG is a novel murine leukocyte-specific GPCR that is induced by the activation of STAT3. Blood 101: 1185-7, 2003. 
142. Shen X, Yang L, Yan S, Wei W, Liang L, Zheng H, Cai X. The effect of FFAR1 on pioglitazone-mediated attenuation of palmitic acid-induced oxidative stress and apoptosis in betaTC6 cells. Metabolism 63: 335-51, 2014.

143. Shi G, Sun C, Gu W, Yang M, Zhang X, Zhai N, Lu Y, Zhang Z, Shou P, Ning G. Free fatty acid receptor 2, a candidate target for type 1 diabetes, induces cell apoptosis through ERK signaling. J Mol Endocrinol 53: 367-80, 2014.

144. Shoelson SE, Herrero L, Naaz A. Obesity, inflammation, and insulin resistance. Gastroenterology 132: 2169-80, 2007.

145. Sina C, Gavrilova O, Forster M, Till A, Derer S, Hildebrand F, Raabe B, Chalaris A, Scheller J, Rehmann A, Franke A, Ott S, Hasler R, Nikolaus S, Folsch UR, Rose-John S, Jiang HP, Li J, Schreiber S, Rosenstiel P. G protein-coupled receptor 43 is essential for neutrophil recruitment during intestinal inflammation. J Immunol 183: 7514-22, 2009.

146. Singh N, Gurav A, Sivaprakasam S, Brady E, Padia R, Shi H, Thangaraju M, Prasad PD, Manicassamy S, Munn DH, Lee JR, Offermanns S, Ganapathy V. Activation of Gpr109a, receptor for niacin and the commensal metabolite butyrate, suppresses colonic inflammation and carcinogenesis. Immunity 40: 128-39, 2014.

147. Sivaprakasam S, Prasad PD, Singh N. Benefits of short-chain fatty acids and their receptors in inflammation and carcinogenesis. Pharmacol Ther 164: 144-51, 2016.

148. Sleeth ML, Thompson EL, Ford HE, Zac-Varghese SE, Frost G. Free fatty acid receptor 2 and nutrient sensing: a proposed role for fibre, fermentable carbohydrates and short-chain fatty acids in appetite regulation. Nutr Res Rev 23: 135-45, 2010.

149. Soga T, Kamohara M, Takasaki J, Matsumoto S, Saito T, Ohishi T, Hiyama H, Matsuo A, Matsushime H, Furuichi K. Molecular identification of nicotinic acid receptor. Biochem Biophys Res Commun 303: 364-9, 2003.

150. Steneberg P, Rubins N, Bartoov-Shifman R, Walker MD, Edlund H. The FFA receptor GPR40 links hyperinsulinemia, hepatic steatosis, and impaired glucose homeostasis in mouse. Cell Metab 1: 245-58, 2005.

151. Stockert JA, Devi LA. Advancements in therapeutically targeting orphan GPCRs. Front Pharmacol 6, 2015.

152. Stone VM, Dhayal S, Brocklehurst KJ, Lenaghan C, Sorhede Winzell M, Hammar M, $\mathrm{Xu}$ X, Smith DM, Morgan NG. GPR120 (FFAR4) is preferentially expressed in pancreatic delta cells and regulates somatostatin secretion from murine islets of Langerhans. Diabetologia 57: 1182-91, 2014. 
153. Sun P, Wang T, Zhou Y, Liu H, Jiang H, Zhu W, Wang H. DC260126: a smallmolecule antagonist of GPR40 that protects against pancreatic beta-Cells dysfunction in $\mathrm{db} / \mathrm{db}$ mice. PLoS One 8: e66744, 2013.

154. Suzuki M, Takaishi S, Nagasaki M, Onozawa Y, Iino I, Maeda H, Komai T, Oda T. Medium-chain fatty acid-sensing receptor, GPR84, is a proinflammatory receptor. $J$ Biol Chem 288: 10684-91, 2013.

155. Tan J, McKenzie C, Potamitis M, Thorburn AN, Mackay CR, Macia L. The role of short-chain fatty acids in health and disease. Adv Immunol 121: 91-119, 2014.

156. Tang H, Lu JY, Zheng X, Yang Y, Reagan JD. The psoriasis drug monomethylfumarate is a potent nicotinic acid receptor agonist. Biochem Biophys Res Commun 375: 562-5, 2008.

157. Tannahill GM, Curtis AM, Adamik J, Palsson-McDermott EM, McGettrick AF, Goel G, Frezza C, Bernard NJ, Kelly B, Foley NH, Zheng L, Gardet A, Tong Z, Jany SS, Corr SC, Haneklaus M, Caffrey BE, Pierce K, Walmsley S, Beasley FC, Cummins E, Nizet V, Whyte M, Taylor CT, Lin H, Masters SL, Gottlieb E, Kelly VP, Clish C, Auron PE, Xavier RJ, O'Neill LA. Succinate is an inflammatory signal that induces IL-1beta through HIF-1alpha. Nature 496: 238-42, 2013.

158. Tazoe H, Otomo Y, Karaki S, Kato I, Fukami Y, Terasaki M, Kuwahara A. Expression of short-chain fatty acid receptor GPR41 in the human colon. Biomed Res 30: 149-56, 2009.

159. Tolhurst G, Heffron H, Lam YS, Parker HE, Habib AM, Diakogiannaki E, Cameron J, Grosse J, Reimann F, Gribble FM. Short-chain fatty acids stimulate glucagon-like peptide-1 secretion via the G-protein-coupled receptor FFAR2. Diabetes 61: 364-71, 2012.

160. Trebaticka J, Dukat A, Durackova Z, Muchova J. Cardiovascular diseases, depression disorders and potential effects of omega-3 fatty acids. Physiol Res, 2017.

161. Trompette A, Gollwitzer ES, Yadava K, Sichelstiel AK, Sprenger N, Ngom-Bru C, Blanchard C, Junt T, Nicod LP, Harris NL, Marsland BJ. Gut microbiota metabolism of dietary fiber influences allergic airway disease and hematopoiesis. Nat Med 20: 159-66, 2014.

162. Tunaru S, Kero J, Schaub A, Wufka C, Blaukat A, Pfeffer K, Offermanns S. PUMA$\mathrm{G}$ and HM74 are receptors for nicotinic acid and mediate its anti-lipolytic effect. Nat Med 9: 352-5, 2003. 
163. Uronis JM, Muhlbauer M, Herfarth HH, Rubinas TC, Jones GS, Jobin C. Modulation of the intestinal microbiota alters colitis-associated colorectal cancer susceptibility. PLoS One 4: e6026, 2009.

164. Vangaveti V, Shashidhar V, Jarrod G, Baune BT, Kennedy RL. Free fatty acid receptors: emerging targets for treatment of diabetes and its complications. Ther $A d v$ Endocrinol Metab 1: 165-75, 2010.

165. Venkatakrishnan AJ, Deupi X, Lebon G, Tate CG, Schertler GF, Babu MM. Molecular signatures of G-protein-coupled receptors. Nature 494: 185-94, 2013.

166. Venkataraman C, Kuo F. The G-protein coupled receptor, GPR84 regulates IL-4 production by $\mathrm{T}$ lymphocytes in response to CD3 crosslinking. Immunol Lett 101: 144-53, 2005.

167. Verdile G, Keane KN, Cruzat VF, Medic S, Sabale M, Rowles J, Wijesekara N, Martins RN, Fraser PE, Newsholme P. Inflammation and Oxidative Stress: The Molecular Connectivity between Insulin Resistance, Obesity, and Alzheimer's Disease. Mediators Inflamm 2015: 105828, 2015.

168. Verma MK, Sadasivuni MK, Yateesh AN, Neelima K, Mrudula S, Reddy M, Smitha R, Biswas S, Chandravanshi B, Pallavi PM, Oommen AM, Jagannath MR, Somesh BB. Activation of GPR40 attenuates chronic inflammation induced impact on pancreatic beta-cells health and function. BMC Cell Biol 15: 24, 2014.

169. Vinolo MA, Hatanaka E, Lambertucci RH, Newsholme P, Curi R. Effects of short chain fatty acids on effector mechanisms of neutrophils. Cell Biochem Funct 27: 48$55,2009$.

170. Violin JD, Crombie AL, Soergel DG, Lark MW. Biased ligands at G-protein-coupled receptors: promise and progress. Trends Pharmacol Sci 35: 308-16, 2014.

171. Wang J, Wu X, Simonavicius N, Tian H, Ling L. Medium-chain fatty acids as ligands for orphan G protein-coupled receptor GPR84. J Biol Chem 281: 34457-64, 2006.

172. Wellen KE, Hotamisligil GS. Inflammation, stress, and diabetes. J Clin Invest 115: 1111-9, 2005.

173. Wise A, Foord SM, Fraser NJ, Barnes AA, Elshourbagy N, Eilert M, Ignar DM, Murdock PR, Steplewski K, Green A, Brown AJ, Dowell SJ, Szekeres PG, Hassall DG, Marshall FH, Wilson S, Pike NB. Molecular identification of high and low affinity receptors for nicotinic acid. J Biol Chem 278: 9869-74, 2003. 
174. Wittenberger T, Schaller HC, Hellebrand S. An expressed sequence tag (EST) data mining strategy succeeding in the discovery of new G-protein coupled receptors. $J$ Mol Biol 307: 799-813, 2001.

175. Wu J, Sun P, Zhang X, Liu H, Jiang H, Zhu W, Wang H. Inhibition of GPR40 protects MIN6 beta cells from palmitate-induced ER stress and apoptosis. J Cell Biochem 113: 1152-8, 2012.

176. Wu P, Yang L, Shen X. The relationship between GPR40 and lipotoxicity of the pancreatic beta-cells as well as the effect of pioglitazone. Biochem Biophys Res Commun 403: 36-9, 2010.

177. Xiong Y, Miyamoto N, Shibata K, Valasek MA, Motoike T, Kedzierski RM, Yanagisawa M. Short-chain fatty acids stimulate leptin production in adipocytes through the G protein-coupled receptor GPR41. Proc Natl Acad Sci U S A 101: 104550, 2004.

178. Yin H, Chu A, Li W, Wang B, Shelton F, Otero F, Nguyen DG, Caldwell JS, Chen YA. Lipid G protein-coupled receptor ligand identification using beta-arrestin PathHunter assay. J Biol Chem 284: 12328-38, 2009.

179. Yonezawa T, Kurata R, Yoshida K, Murayama MA, Cui X, Hasegawa A. Free fatty acids-sensing $\mathrm{G}$ protein-coupled receptors in drug targeting and therapeutics. Curr Med Chem 20: 3855-71, 2013.

180. Youn JY, Siu KL, Lob HE, Itani H, Harrison DG, Cai H. Role of vascular oxidative stress in obesity and metabolic syndrome. Diabetes 63: 2344-55, 2014.

181. Yousefi S, Cooper PR, Potter SL, Mueck B, Jarai G. Cloning and expression analysis of a novel G-protein-coupled receptor selectively expressed on granulocytes. J Leukoc Biol 69: 1045-52, 2001.

182. Zaibi MS, Stocker CJ, O'Dowd J, Davies A, Bellahcene M, Cawthorne MA, Brown AJ, Smith DM, Arch JR. Roles of GPR41 and GPR43 in leptin secretory responses of murine adipocytes to short chain fatty acids. FEBS Lett 584: 2381-6, 2010.

183. Zandi-Nejad K, Takakura A, Jurewicz M, Chandraker AK, Offermanns S, Mount D, Abdi R. The role of HCA2 (GPR109A) in regulating macrophage function. Faseb $j$ 27: 4366-74, 2013.

184. Zhang JH, Ferrante A, Arrigo AP, Dayer JM. Neutrophil stimulation and priming by direct contact with activated human T lymphocytes. J Immunol 148: 177-81, 1992. 
185. Zhang Q, Yang H, Li J, Xie X. Discovery and Characterization of a Novel SmallMolecule Agonist for Medium-Chain Free Fatty Acid Receptor G Protein-Coupled Receptor 84. J Pharmacol Exp Ther 357: 337-44, 2016.

186. Zhao J, Wang H, Shi P, Wang W, Sun Y. GPR120, a potential therapeutic target for experimental colitis in IL-10 deficient mice. Oncotarget 8: 8397-8405, 2017.

187. Zuo L, Zhou T, Pannell BK, Ziegler AC, Best TM. Biological and physiological role of reactive oxygen species--the good, the bad and the ugly. Acta Physiol (Oxf) 214: 329-48, 2015. 
Table 1. Metabolite-sensing GPCRs involved in immunometabolic signalling

\begin{tabular}{|c|c|c|c|}
\hline Receptor & Metabolite Ligands & $\begin{array}{l}\text { G protein } \\
\text { coupling }\end{array}$ & Expression \\
\hline \multicolumn{4}{|c|}{ Long-chain fatty acid receptors } \\
\hline GPR120(FFAR4) & $\begin{array}{l}\text { LCFAs (C12-C22): } \\
\text { unsaturated, } \omega-3 \text { and } \omega-6 \\
\text { fatty acids }\end{array}$ & $\mathrm{G}_{\mathrm{ai}} / \mathrm{G}_{\mathrm{aq}}$ & $\begin{array}{l}\text { Immune cells: macrophages } \\
\text { Intestine enteroendocrine cells } \\
\text { Pancreatic cells } \\
\text { Adipocytes }\end{array}$ \\
\hline GPR40(FFAR1) & $\begin{array}{l}\text { LCFAs (C12-C22), MCFAs } \\
(\text { C7-C12), and CLAs. }\end{array}$ & $G_{\alpha q}$ & $\begin{array}{l}\text { Pancreatic } \beta \text { cells } \\
\text { Enteroendocrine cells } \\
\text { Immune cells: neutrophils } \\
\text { Neurons } \\
\text { Taste buds cells }\end{array}$ \\
\hline \multicolumn{4}{|c|}{ Medium-chain fatty acid receptors } \\
\hline GPR84 (EX33) & $\begin{array}{l}\text { MCFAs (C2-C6): Capric } \\
\text { acid, decanoic acid and } \\
\text { undecanoic acid. }\end{array}$ & $\mathrm{G}_{\mathrm{al}}$ & $\begin{array}{l}\text { Immune cells: leukocytes, mainly macrophages } \\
\text { and microglia cells }\end{array}$ \\
\hline \multicolumn{4}{|c|}{ Short-chain fatty acid receptors } \\
\hline GPR43 (FFAR2) & $\begin{array}{l}\text { SCFAs (C2-C6): Acetate, } \\
\text { Propionate, Butyrate }\end{array}$ & $G_{\alpha 1} / G_{\alpha q}$ & $\begin{array}{l}\text { Immune cells: neutrophils and eosinophils } \\
\text { Enteroendocrine cells } \\
\text { Adipocytes } \\
\text { Pancreatic islet cells }\end{array}$ \\
\hline GPR41 (FFAR3) & $\begin{array}{l}\text { SCFAs (C2-C6): Acetate, } \\
\text { Propionate, Butyrate }\end{array}$ & $\mathrm{G}_{\mathrm{ai}}$ & $\begin{array}{l}\text { Immune cells: peripheral blood mononuclear } \\
\text { cells and macrophages } \\
\text { Enteroendocrine cells } \\
\text { Pancreatic islet cells } \\
\text { Neurons }\end{array}$ \\
\hline \multicolumn{4}{|c|}{ Succinate receptors } \\
\hline GPR91 (SUCNR1) & Succinate & $\mathrm{G}_{a \mathrm{i}} / \mathrm{G}_{\alpha \mathrm{a}}$ & $\begin{array}{l}\text { Immune cells: dendritic cells, macrophages and } \\
\text { platelets } \\
\text { Kidney: macula densa and endotelial cells } \\
\text { Adipocytes } \\
\text { Retinal neurons } \\
\text { Other tissues: liver, heart, intestine and spleen }\end{array}$ \\
\hline \multicolumn{4}{|c|}{ Niacin receptors } \\
\hline $\begin{array}{l}\text { GPR109A } \\
\text { (HCA2/NIACR1) }\end{array}$ & $\begin{array}{l}\text { 3-hydroxybutyrate and } \\
\text { SCFAs: butyrate }\end{array}$ & $G_{x i}$ & $\begin{array}{l}\text { Immune cells: macrophages, dendritic cells } \\
\text { Adipocytes } \\
\text { Langerhans cells } \\
\text { Intenstinal epithelial cells } \\
\text { Keratinocytes }\end{array}$ \\
\hline $\begin{array}{l}\text { GPR109B } \\
\text { (HCA3/NIACR2) }\end{array}$ & 3-hydroxyoctanoate & $\mathrm{G}_{a i}$ & $\begin{array}{l}\text { Immune cells: macrophages, neutrophils } \\
\text { Adipocytes } \\
\text { Colon epithelial cells }\end{array}$ \\
\hline GPR81 (HCA1) & Lactate & $G_{a i}$ & Adipocytes \\
\hline
\end{tabular}




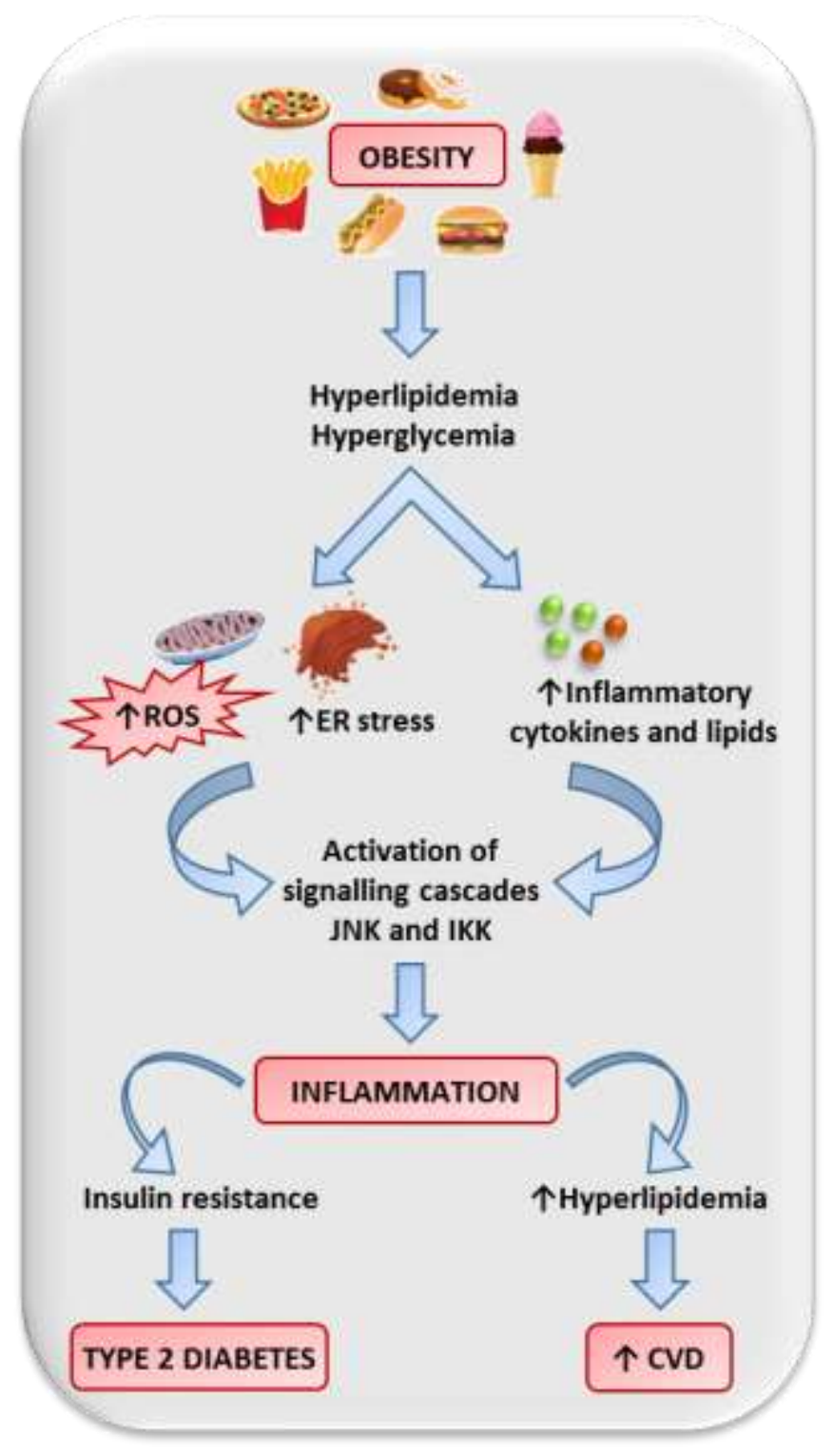

Figure 1. Illustrative flowchart that represents the role that inflammation and oxidative stress play in metabolic disease.

Activation of intracellular signalling pathways aggravates the inflammatory process leading to severe consequences such as insulin resistance (T2D) and increased risk of CVD. 


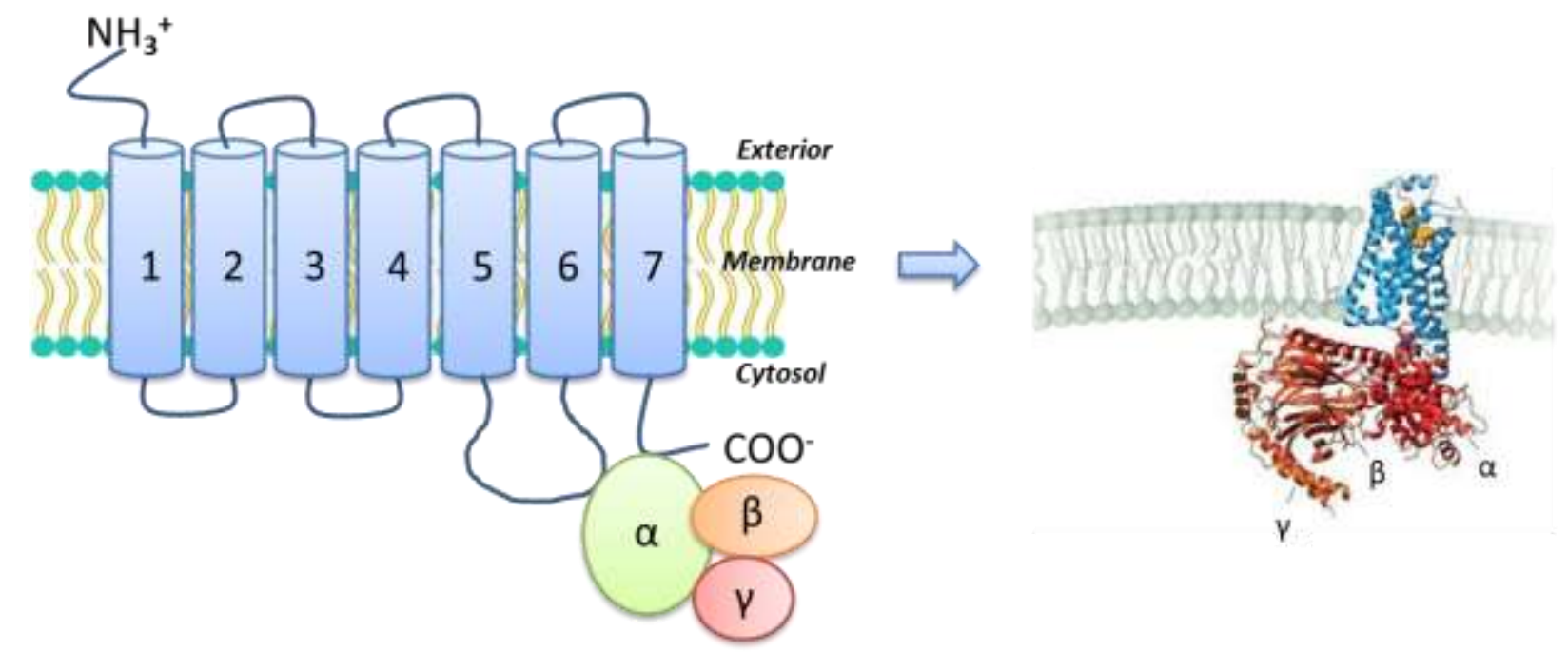

\begin{tabular}{|c|c|c|c|c|}
\hline Long-chain fatty acid receptors & $\begin{array}{c}\text { Medium-chain fatty acid } \\
\text { receptors }\end{array}$ & Short-chain fatty acid receptors & Succinate receptor & Niacin receptors \\
\hline GPR120 & GPR84 & GPR109A/GPR109B/GPR81 \\
\hline
\end{tabular}

Figure 2. General structure of GPCRs. Top left: the snake diagram shows the seven transmembrane domains with the extracellular N-terminus and the C-terminus located inside the cell. Top right: proposed molecular structure of a GPCR in complex with $\mathrm{G} \alpha \beta \gamma$ (taken from the studies of Brian Kobilka and Robert Lefkowitz in GPCRs that gave them the Nobel Prize in Chemistry in 2012 (9)). The representation shows the seven transmembrane helices which are arranged in an approximately circular fashion within the membrane plane. The yellow structure represents the GPCR ligand within the binding site which is in the middle of the helices, being accessible from the extracellular side. Bottom panel: different $G$ protein coupling of the metabolite sensing GPCRs included in this review. 


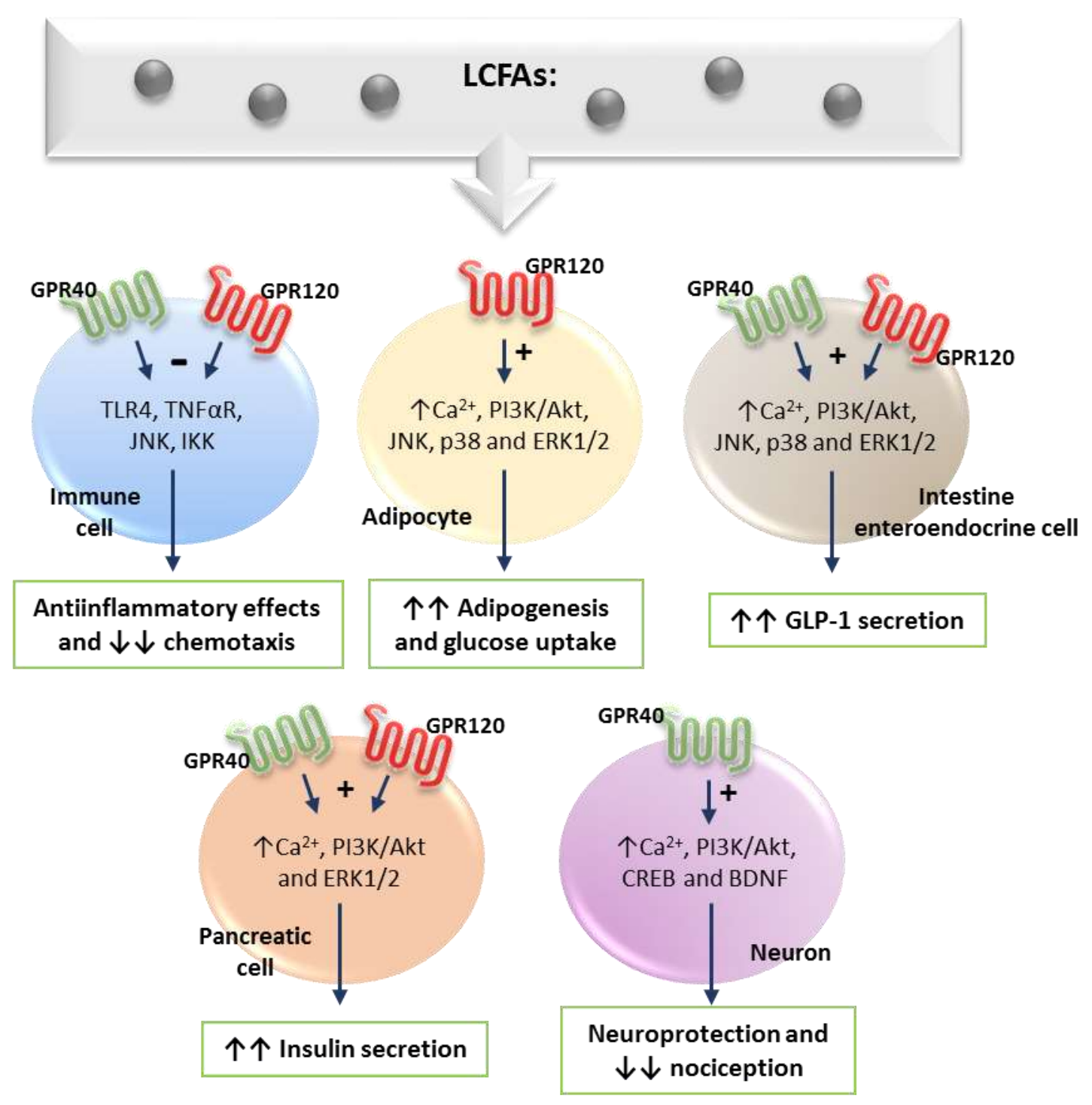

Figure 3. Proposed mechanism of action of long-chain fatty acid receptors (GPR120 and GPR40) in different cell types.

Top left panel: Both GPR40 and GPR120 are expressed in immune cells and signal via different intracellular cascades including TLR4, TNFa, JNK and IKK involved in inflammation and migration. Top middle panel: LCFA-induced GPR120 signaling elicits adipogenesis and increased glucose uptake in adipose tissue. Top right panel: GPR40 and GPR120 regulate the secretion of GLP-1 in enteroendocrine cells. Bottom left panel: In pancreatic cells, both GPR40 and GPR120 promote LCFA-mediated insulin secretion. Bottom right panel: GPR40 is expressed in neurons exerting a neuroprotective role and decreasing nociception. 

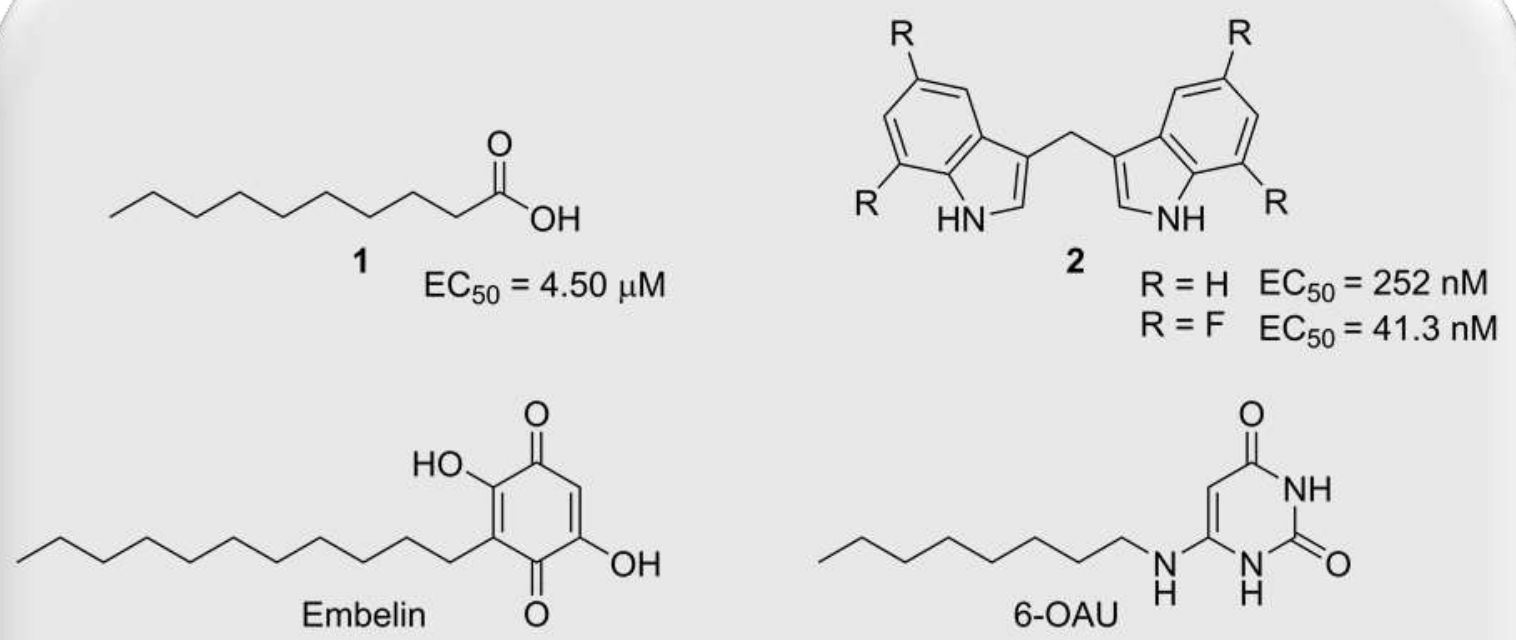

$3 E_{50}=122 \mathrm{nM}$

$4 \quad \mathrm{EC}_{50}=653 \mathrm{nM}$

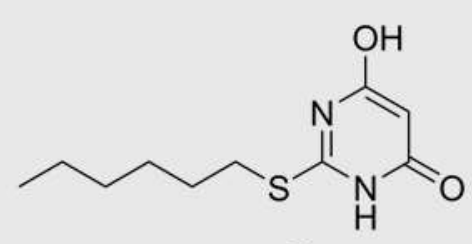

$5 \quad \mathrm{EC}_{50}=139 \mathrm{nM}$

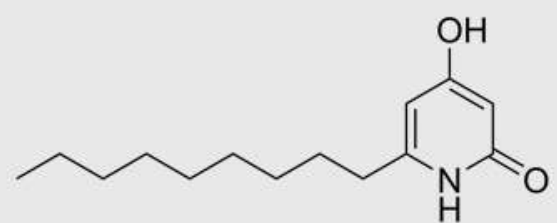

$6 \quad \mathrm{EC}_{50}=189 \mathrm{pM}$

Figure 4. Chemical structures of reported GPR84 physiological agonists and GPR84 tool compounds. 


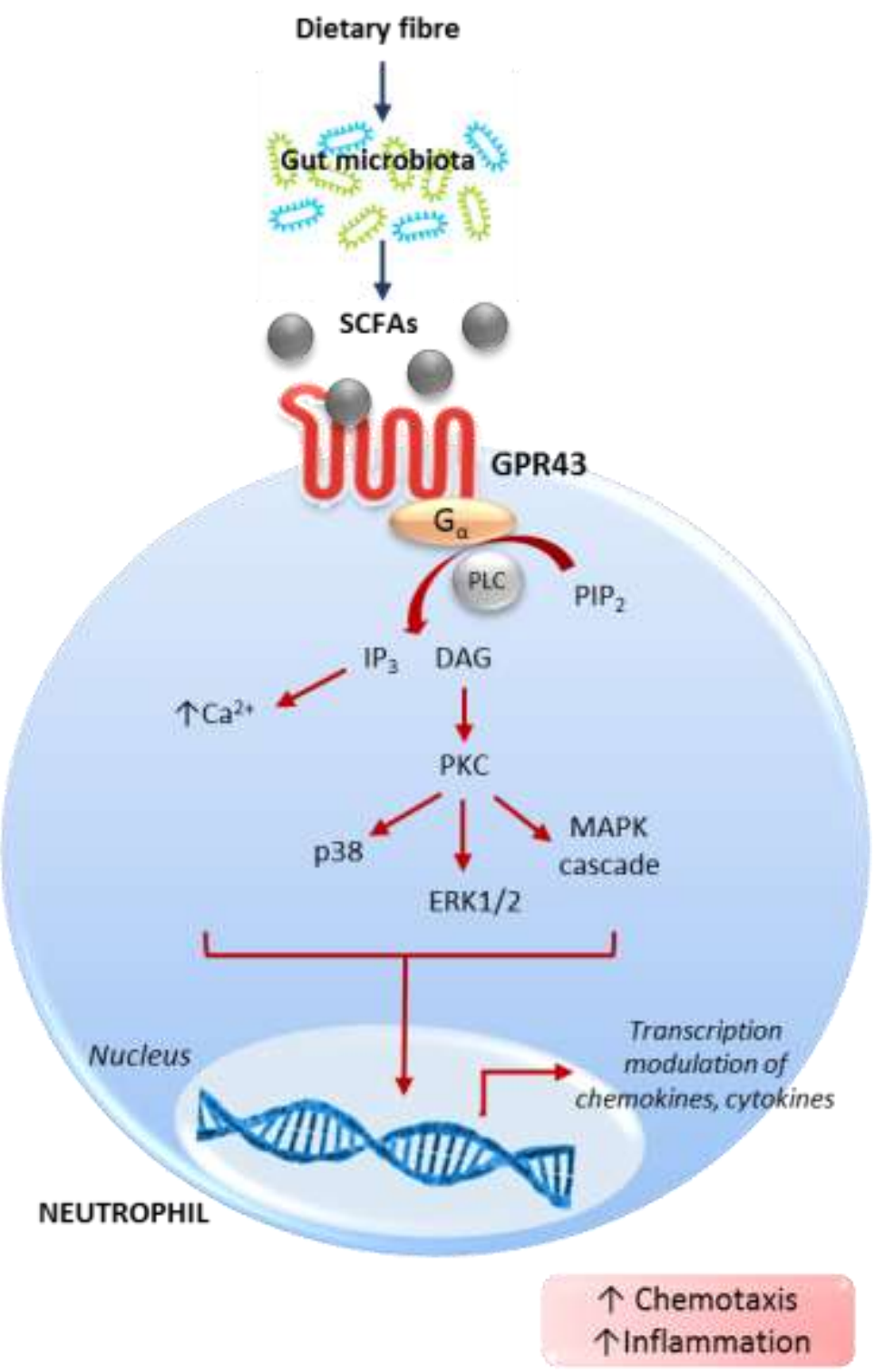

Figure 5. SCFA receptor GPR43 proposed mechanism of action in neutrophils.

SCFA-induced GPR43 signaling elicits chemotaxis and increased inflammatory profile in neutrophils by activating different intracellular signalling pathways including MAPK kinases, ERK and p38. 


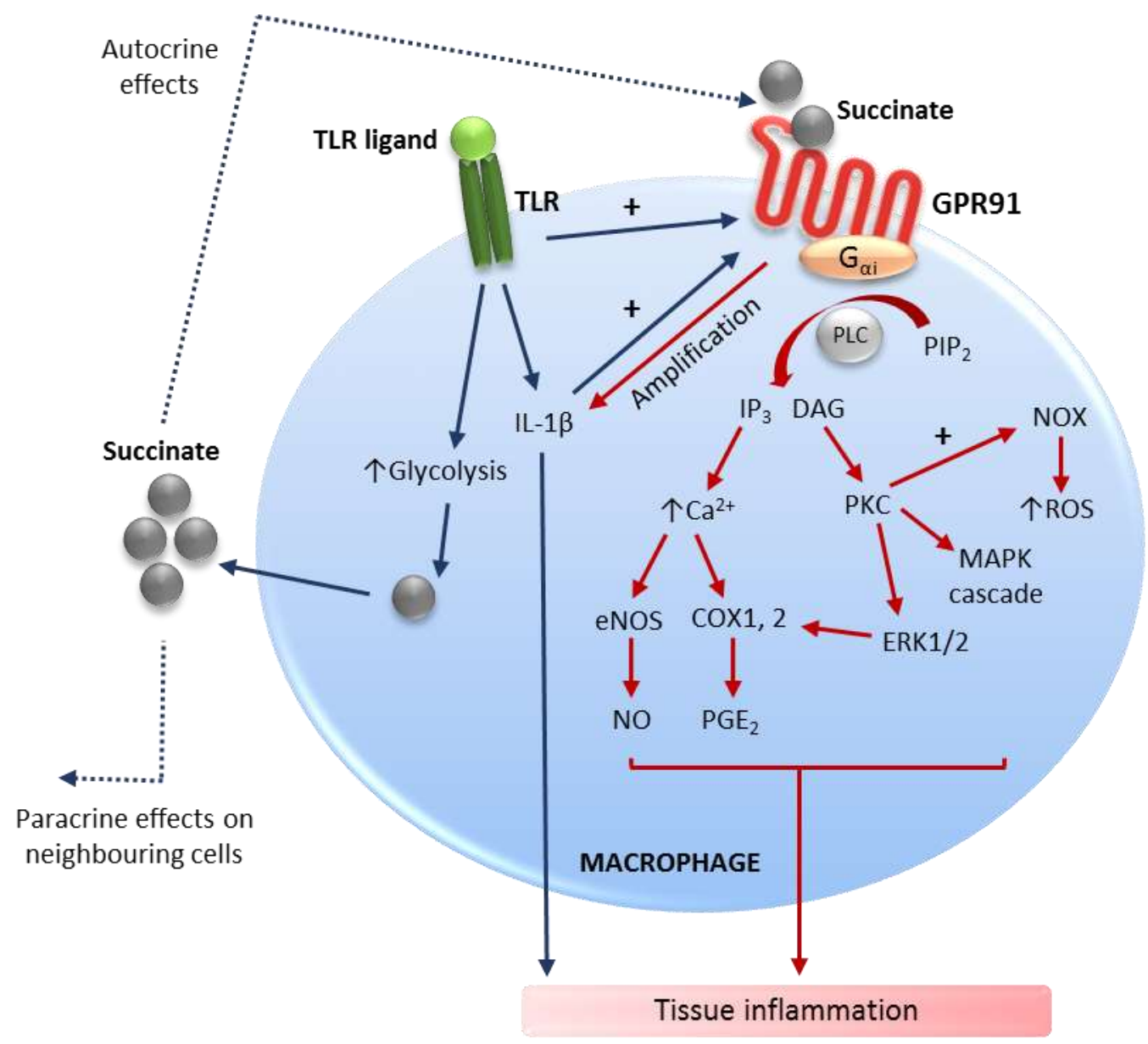

Figure 6. Succinate receptor proposed mechanism of action.

Succinate-mediated GPR91 signalling (red arrows) activates inflammatory cascades in macrophages that lead to tissue inflammation. GPR91-driven increased glycolysis (blue arrows) promotes the synthesis of succinate that exerts both autocrine effects in macrophages and paracrine effects on neighbouring cells. Modified from LittlewoodEvans et al. (86). 


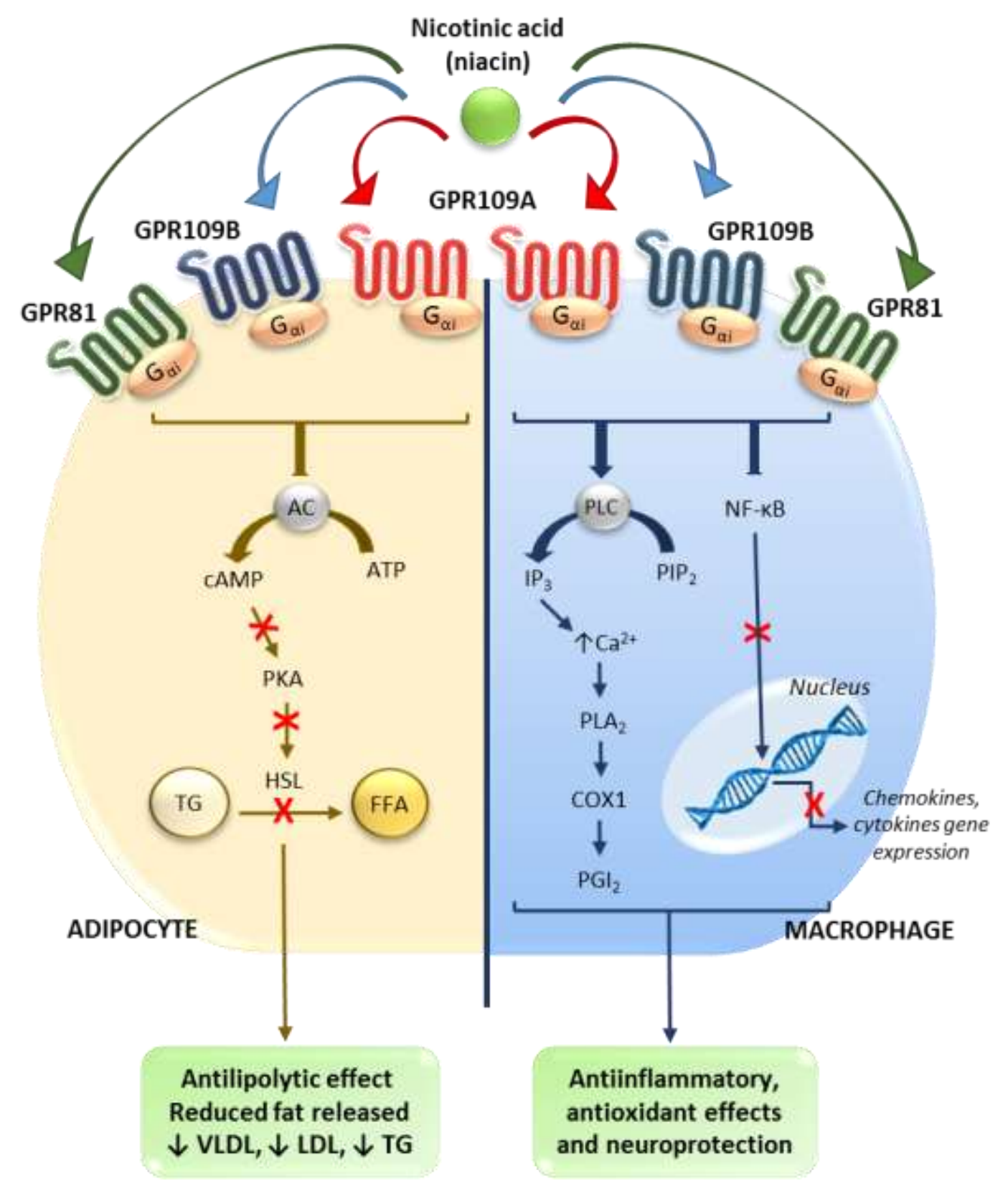

Figure 7. Niacin receptors mechanism of action.

Left part: In adipocytes, nicotinic acid binds niacin receptors leading to a decrease in free fatty acids mobilization from adipose tissue to the liver resulting in a reduction of TG and thus LDL and VLDL synthesis. Right part: In macrophages and microglia, niacin receptor-mediated signalling induces antioxidant and neuroprotective effects and reduces inflammation. 